*aMIS View/Print Document Cover Sheet

This document was retrieved from the Boeing ISEARCH System.

Accession \#: D196054421

Document \#: SD-WM-ER-420

Title/Desc:

TANK 241BY106 HEADSPACE GAS \& VAPOR

CHARACTERIZATION RESAULTS FOR SAMPLES COLLECTED IN 5/1994 \& 71994 
Paga 1 of 2 Proj:

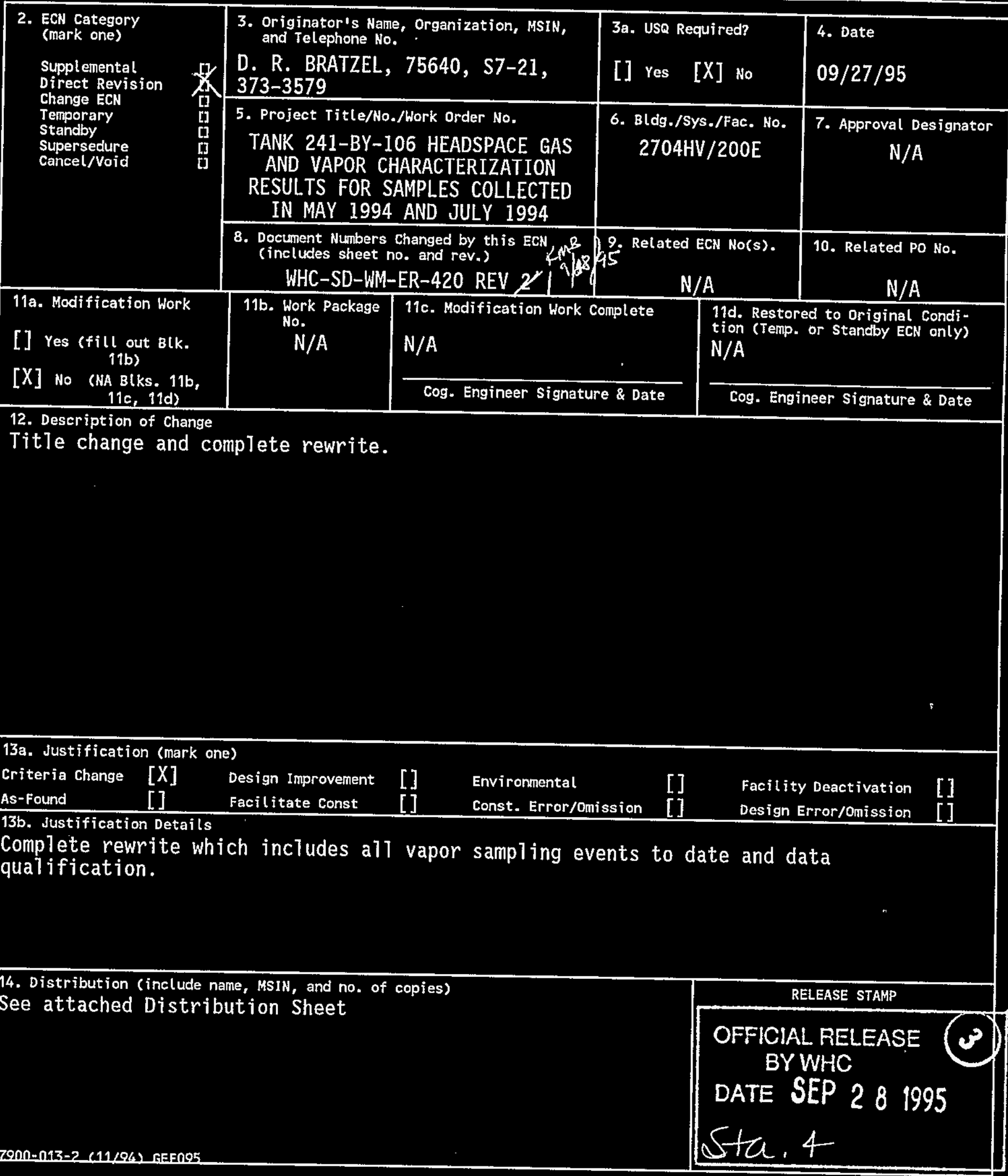




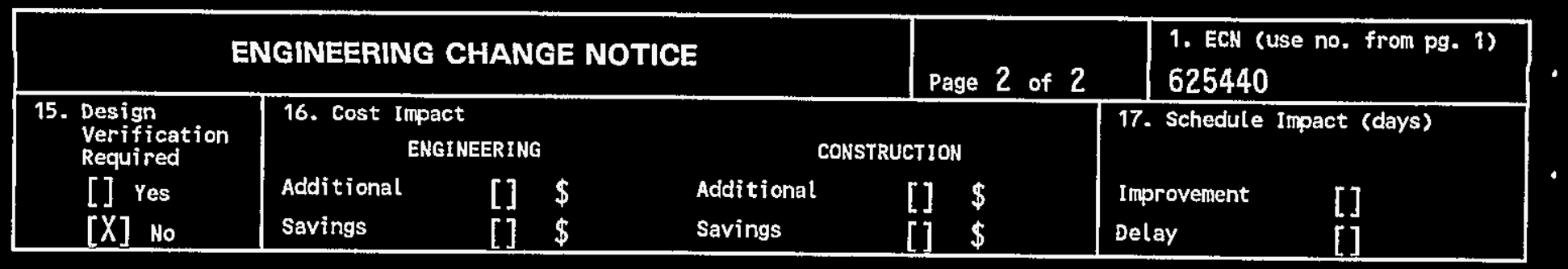

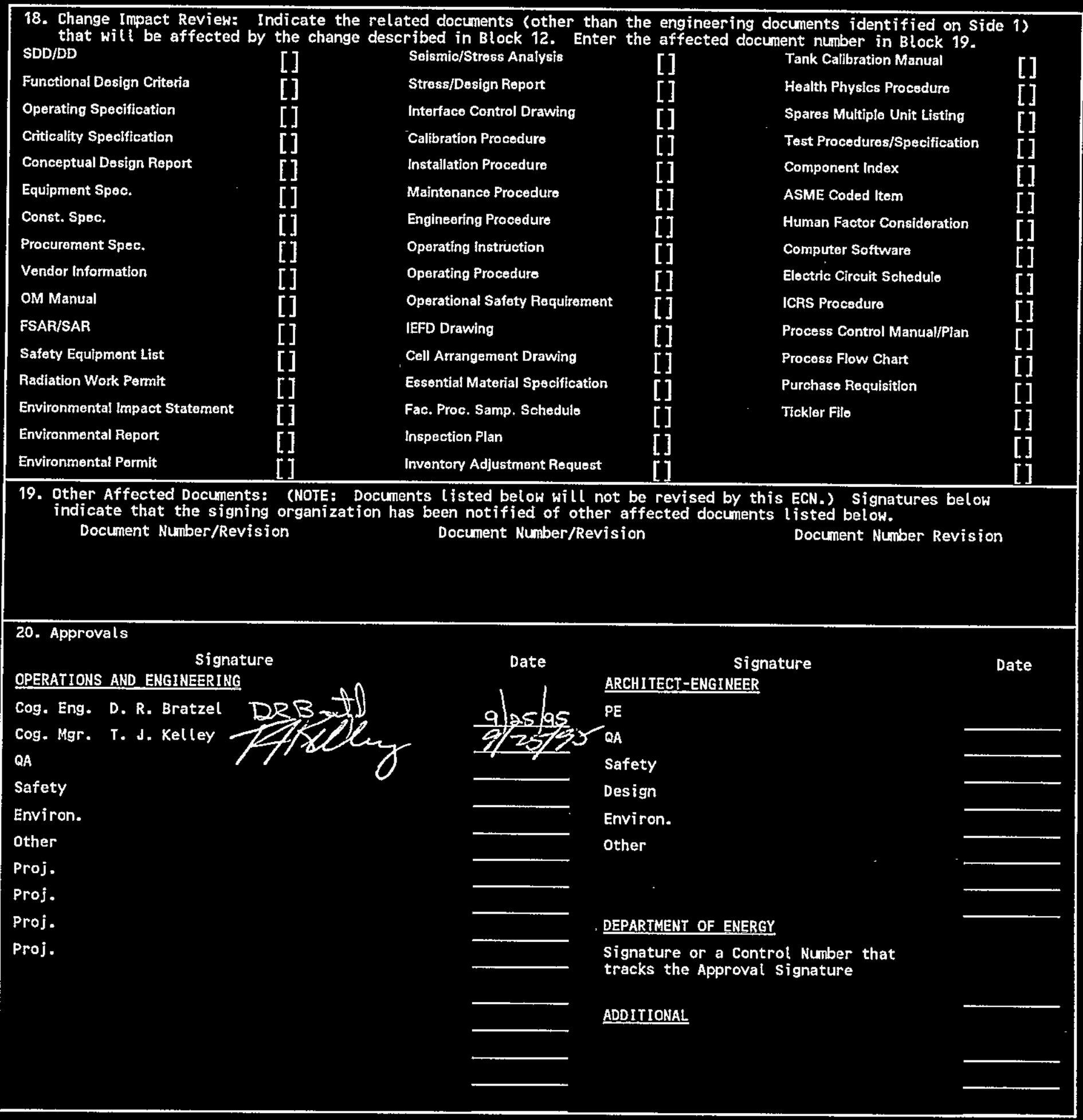




\section{RELEASE AUTHORIZATION}

Document Number: WHC-SD-WM-ER-420, REV 2

$\begin{array}{ll}\text { Tank 241-BY-106 Headspace Gas and Vapor } \\ \text { Document Title: } & \text { Characterization Results for Samples Collected in }\end{array}$

May 1994 and Juiy 1994

Release Date: $\quad 9 / 28 / 95$

\section{This document was reviewed following the procedures described in WHC-CM-3-4 and is:}

\section{APPROVED FOR PUBLIC RELEASE}

WHC Information Release Administration Specialist:
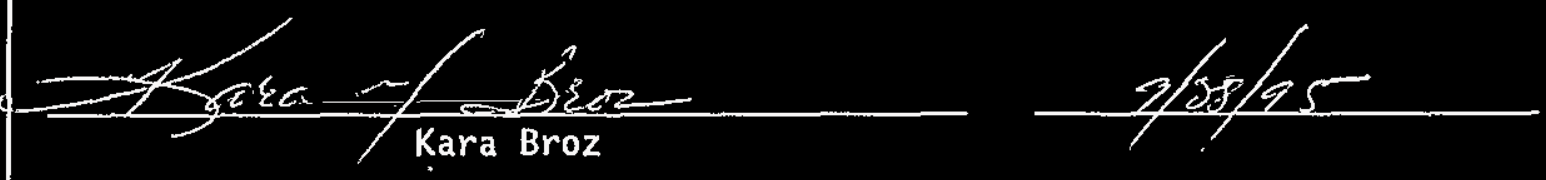

TRADEMARK DISCLAIMER. Reference here in to any specific commercial product, process, or service by trade name, trademark, manufacturer, or otherwise, does not necessarily constitute or imply its endorsement, recommendation, or favoring by the United States Government or any agency thereof or its contractors or subcontractors.

This report has been reproduced from the best available copy. Available in paper copy. Printed in the United States of America. To obtain copies of this report, contact:

Westinghouse Hanford Company - Document Control Services

P.0. Box 1970, Mailstop H6-08, Richland, WA 99352

Telephone: (509) 372-2420; Fax: (509) 376-4989 
<smiles>C1CC1</smiles> 
2. Title

TANK 241-BY-106 HEADSPACE GAS AND VAPOR CHARACTERIZATION RESULTS FOR SAMPLES COLLECTED IN MAY 1994 AND JULY 1994

5. Key Words

CHARACTERIZATION OBJECTIVES, TANK HEADSPACE, SAMPLING EVENT, INORGANIC GASES, ORGANIC VAPORS
3. Number

WHC-SD-HW-ER-420
4. Rev No.

2

6. Author

Name: D. R. BRATZEL

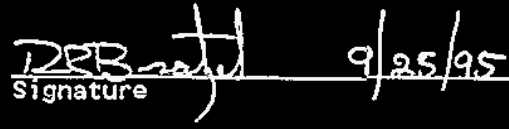

Organization/Charge code

$75640 / \mathrm{NABI}$

\section{Abstract}

Significant changes have been made to alt of the original vapor characterization reports. This report documents specific headspace gas and vapor characterization results for all vapor sampling events to date. In addition, changes have been made to the original vapor reports to qualify the data based on quality assurance issues associated with the performing laboratories.

OFFICIAL RELEASE BYWHC 


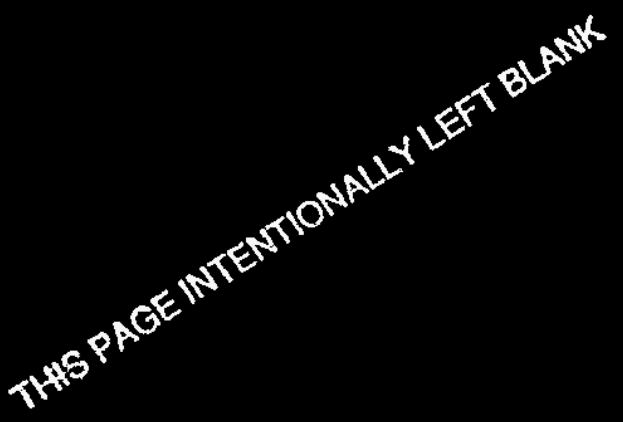


(2) Title

TANK 241-BY-106 HEADSPACE GAS AND VAPOR CHARACTERIZATION RESULTS FOR SAMPLES COLLECTED IN MAY 1994 AND JULY 1994

CHANGE CONTROL RECORD

\begin{tabular}{|c|l|l|l|}
\hline (3) Revision & (4) Description of Change - Replace, Add, and Delete Pages & \multicolumn{2}{|c|}{ Authorized for Release } \\
\cline { 3 - 5 } & $\begin{array}{l}\text { WHC-SD-WM-ER-420, REV. 0, EDT 607554 } \\
\text { May 31, 1995 }\end{array}$ & & \\
\hline 1 & $\begin{array}{l}\text { Made editorial changes and added } \\
\text { information in organic vapor chapter. ECN } \\
623543\end{array}$ & & \\
\hline 2 RS & $\begin{array}{l}\text { Complete revision and title change. ECN } \\
625440\end{array}$ & & \\
\hline & & & \\
\hline & & & \\
\hline & & & \\
\hline & & & \\
\hline & & & \\
\hline
\end{tabular}




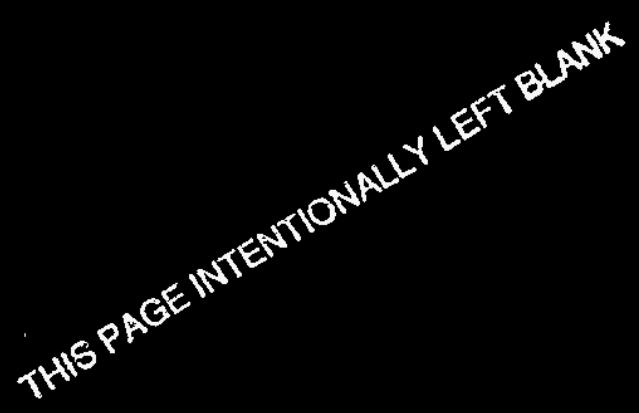


WHC-SD-WM-ER-420

Revision 2

UC-2070

\title{
Tank 241-BY-106 Headspace Gas and Vapor Characterization Results for Samples Collected in May 1994 and July 1994
}

\author{
J. L. Huckaby \\ Pacific Northwest Laboratories \\ D. R. Bratzel \\ Westinghouse Hanford Company
}

Date Published

September 1995

Prepared for the U.S. Department of Energy

Office of Environmental Restoration and

Waste Management

$\begin{array}{ll}\text { Westinghouse } & \text { P.O Box } 1970 \\ \text { Hanford Company Richland, Washington }\end{array}$

Management and Operations Contractor for the

U.S. Department of Energy under Contract DE-ACO6-87RL10930 


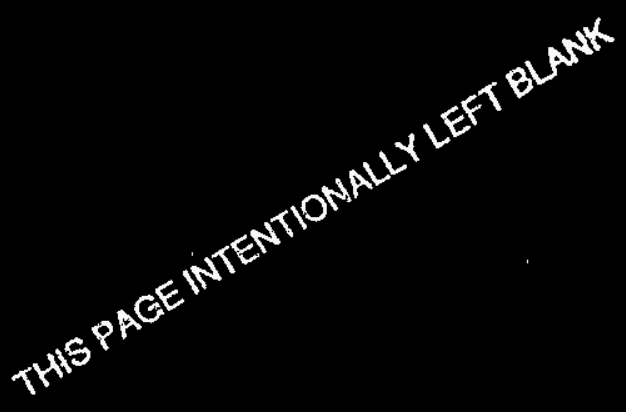




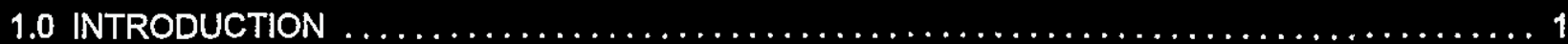

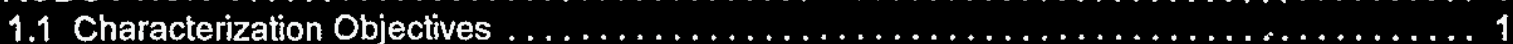

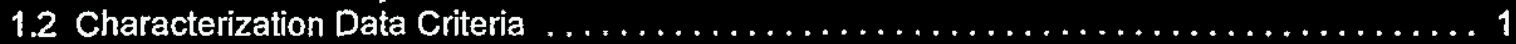

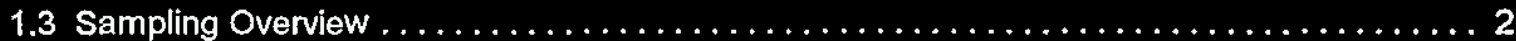

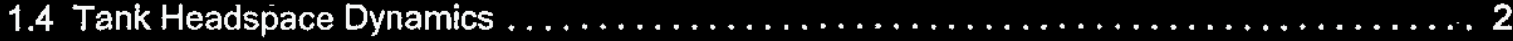

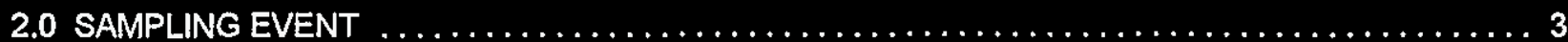

2.1 May 1994 In Situ Sampling Event .................................. 3

2.2 July 1994 Vapor Sampling System Sampling Event . . . . . . . . . . . . . . . . . 3

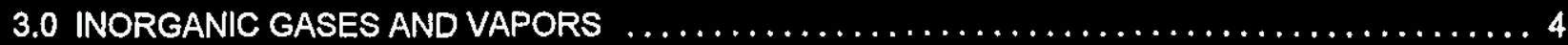

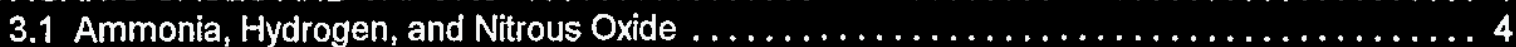

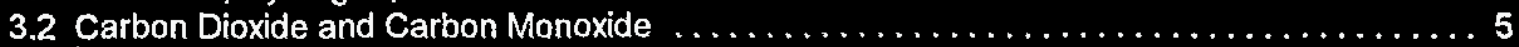

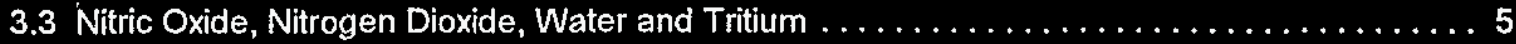

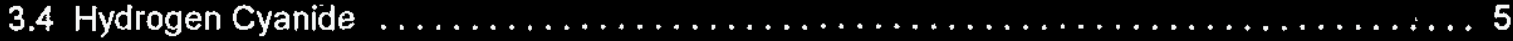

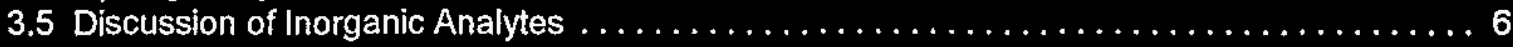

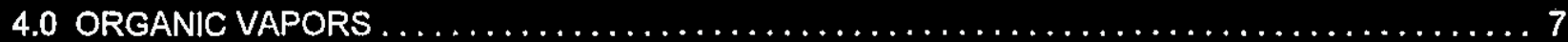

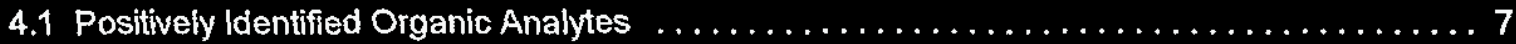

4.2 Tentatively Identified Organic Analytes $\ldots \ldots \ldots \ldots \ldots \ldots \ldots \ldots \ldots \ldots \ldots \ldots \ldots \ldots \ldots$

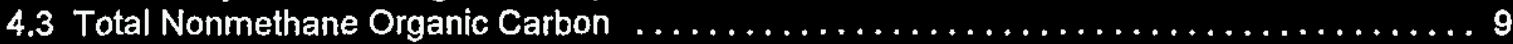

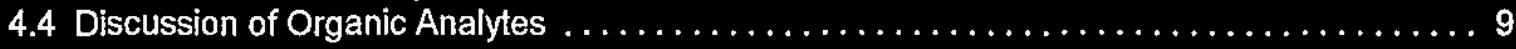

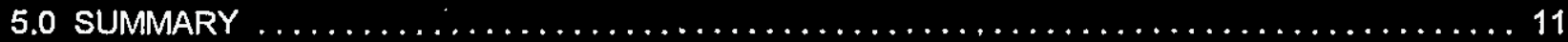

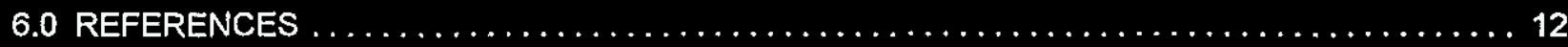

Acronyms and Abbreviations

$\begin{array}{ll}\text { CES } & \text { consensus exposure standard } \\ \text { EPA } & \text { Environmental Protection Agency } \\ \text { GC } & \text { gas chromatograph } \\ \text { GCMS } & \text { gas chromatograph/mass spectrometer } \\ \text { ISS } & \text { in situ sampling } \\ \text { LFL } & \text { lower flammability limit } \\ \text { MS } & \text { mass spectrometer } \\ \text { NFPA } & \text { National Fire Protection Association } \\ \text { NPH } & \text { normal paraffinic hydrocarbon } \\ \text { OGIST } & \text { Oregon Graduate Institute of Science and Technology } \\ \text { ORNL } & \text { Oak Ridge National Laboratory } \\ \text { PNL } & \text { Pacific Northwest Laboratory } \\ \text { ppmv } & \text { parts per million by volume, } 1 \text { ppmv }=10^{-4} \text { vol\% } \\ \text { TNMOC } & \text { total nonmethane organic carbon } \\ \text { TST } & \text { triple sorbent trap } \\ \text { Vol\% } & \text { percent by volume, 1 vol\% }=10,000 \mathrm{ppmv} \\ \text { VSS } & \text { vapor sampling system } \\ \text { WHC } & \text { Westinghouse Hanford Company }\end{array}$


WHC-SD-WM-ER-420 REV. 2

\section{Acknowledgements}

The author wishes to thank Chris Simonen for her work verifying data and generating tables, and Shas Mattigod for his help with the construction and reviews of this document. 
WHC-SD-WM-ER-420 REV. 2

Tank 241-BY-106 Headspace Gas and Vapor Characterization Results

for Samples Collected in May 1994 and July 1994

\subsection{INTRODUCTION}

\subsection{Characterization Objectives}

Tank BY-106 headspace gas and vapor samples were collected and analyzed to help determine the potential risks of fugitive emissions to tank farm workers. The drivers and objectives of waste tank headspace sampling and analysis are discussed in Program Plan for the Resolution of Tank Vapor Issues (Osborne and Huckaby 1994). This report primarily discusses results from the July 1994 sampling event, but also includes selected results of the May 1994 sampling event. The tank BY-106 headspace was sampled in May 1994 in accordance with Safety Assessment for Gas Sampling All Ferrocyanide Tanks (Farley 1991), and in July 1994 in accordance with Data Quality Objectives for Generic In-Tank Health and Safety lssue Resolution (Osborne et al. 1994).

\subsection{Characterization Data Criteria}

Data Quality Objectives for Generic In-Tank Health and Safety Issue Resolution describes parameters for data collection to ensure appropriate conclusions can be drawn from the data. Tank headspace characterization data was collected to help in the evaluation of 1) headspace flammability, and 2) identification and quantification of compounds of toxicological concern.

Single Shell Tank Interim Operational Safety Requirements (Dougherty 1995) specifies that combustible constituents in tank headspaces be maintained below $25 \%$ of the lower flammability limit (LFL). This essentially agrees with National Fire Protection Association requirements that combustible concentrations be maintained at or below $25 \%$ of the LFL (NFPA 1992). Current governing operating specifications for Watchlist tanks, such as tank BY-106, specify that combustible constituents be maintained at or below $20 \%$ of the LFL (WHC 1995a).

Headspace charactérization data are used by Westinghouse Hanford Company (WHC) Tank Waste Remediation Systems Industrial Hygiene as source term data in the industrial hygiene strategy to protect workers from tank fugitive emissions. Because selection of worker protective equipment must be based on industrial hygiene monitoring of the work place and not on source term data (29 CFR 1910.120), tank headspace characterization data can not be used for this purpose. Furthermore, because there are mechanisms by which headspace constituents can be either diluted or concentrated as they are released to the atmosphere, the headspace characterization data should not be considered to be representative of emissions at the point of emission.

These statements notwithstanding, the data quality objectives document specifies that the industrial hygiene group be advised if constituents with toxicological properties exceed $50 \%$ of the appropriate consensus exposure standard (CES) for non-carcinogens, or $10 \%$ of the appropriate CES for carcinogens. A CES is defined as the most stringent of known regulatory or recommended toxicological values for the workplace (Osborne et al. 1994). 


\subsection{Sampling Overview}

Tank BY-106 was vapor sampled in May 1994 using the in situ sampling (ISS) method, and again in July 1994 using the more robust vapor sampling system (VSS) method. Because the ISS sample volume flow measurement used during the May 1994 event was inherently less accurate than that of the VSS, the sorbent trap samples from the ISS event are not considered to be equivalent to those from the VSS sampling event (Huckaby and Babad 1995). Furthermore, there are other discrepancies between results from the ISS and VSS methods that are not understood (Huckaby 1994a), and until the ISS method has been validated and the discrepancies resolved, results from early ISS events should be considered suspect.

Nevertheless, a brief description of the ISS event and hydrogen cyanide sampling results from the May 1994 ISS event are presented below, because this analyte was not sampled for during the VSS event. Huckaby and Babad (1995) describe the bases for using the ISS method for hydrogen cyanide, and why it was not sampled for during the VSS event. All other results presented here are from the July 1994 VSS sampling event.

Samples collected are thought to have been representative of the tank headspace when the tank was sampled (Meacham et al. 1995), and sample analyses were designed to provide a reasonably accurate and complete characterization of the significant headspace constituents. No assessment has been made of how the tank BY-106 headspace composition changes with time, though studies of tank C-103 suggest that composition changes probably occur very slowly in passively ventilated tanks, such as tank BY-106 (Huckaby and Story 1994).

\subsection{Tank Headspace Dynamics}

Tank BY-106 is the third tank in a 3-tank cascade with tanks BY-104 and BY-105. It is connected to tank BY-105 via a 7.4-cm (2.9-in.) inside diameter, 7.6-m (25-ft) long underground cascade line. Tanks BY-104 and BY-105 are connected by a similar line. Since these cascade lines connect the headspaces of these tanks, gases and vapors originating from the wastes in tank BY-104 or BY-105 may be transferred to tank BY-106 (unless the cascade lines are obstructed).

The cascade of tanks BY-104, BY-105, and BY-106 is passively ventilated, which means that the tanks are allowed to exhale air, waste gases, and vapors as the barometric pressure falls, and inhale ambient air as the barometric pressure rises. Each of these tanks has its own filtered breather riser. Barometric pressure typically rises and falls on a diurnal cycle, producing an average daily exchange of air equal to about $0.46 \%$ of each tank headspace (Huckaby 1994b). Changes in the concentrations of tank headspace constituents due to barometric pressure changes are consequently very slow. 


\subsection{SAMPLING EVENT}

\subsection{May 1994 In Situ Sampling Event}

Tank BY-106 was sampled using ISS methods on May 4, 1994 by WHC Sampling and Mobile Laboratories. This sampling was conducted to satisfy requirements of Safety Assessment for Gas Sampling All Ferrocyanide Tanks (Farley 1991). Samples for hydrogen cyanide were collected from a point approximately $7.9 \mathrm{~m}$ below the top of the flange on riser 3, between 9:45 a.m. and 10:45 a.m.

Huckaby et al. (1995) give a general description of the ISS method and equipment. Pingel (1994) provides field sampling information for the tank BY-106 May 1994 ISS event, and Mahon (1995) provides revised sample volume measurements. In addition to the hydrogen cyanide results presented below, Pool et al. (1995) provide sample preparation and analysis results for selected organic and inorganic vapors. SUMMA' ${ }^{\mathrm{TM}}$ canister samples collected during the May 1994 ISS event were prepared and analyzed Oregon Graduate Institute of Science and Technology (OGIST) and these results are reported by Rasmussen (1994a).

\subsection{July 1994 Vapor Sampling System Sampling Event}

Headspace gas and vapor samples were collected from tank BY-106 using the vapor sampling system (VSS) on July 8, 1994 by WHC Sampling and Mobile Laboratories (WHC 1995b). Sample collection and analysis were performed as directed by the sample and analysis plan ${ }^{1}$ (WHC 1995b, Appendix A). The tank headspace temperature was determined to be $27^{\circ} \mathrm{C}$. Air from the tank BY-106 headspace was withdrawn via a heated sampling probe mounted in riser 10B, and transferred via heated tubing to the VSS sampling manifold. All heated zones of the VSS were maintained at approximately $65^{\circ} \mathrm{C}$.

Sampling media were prepared and analyzed by WHC, Oak Ridge National Laboratories (ORNL), Pacific Northwest Laboratories (PNL), and OGIST through á contract with Sandia National Laboratories. The 46 tank air samples and 2 ambient air control samples collected are listed in Table 2-1 by analytical laboratory. Table 2-1 also lists the 10 trip blanks provided by the laboratories.

A general description of vapor sampling and sample analysis methods is given by Huckaby et al. (1995). The sampling equipment, sample collection sequence, sorbent trap sample air flow rates and flow times, chain of custody information, and a discussion of the sampling event itself are given in WHC 1995b and references therein.

\footnotetext{
1 The current requirement that sampling and analysis parameters be specified by a tank characterization plan was not in effect for gas and vapor sampling until October 1, 1994.
} 


\subsection{INORGANIC GASES AND VAPORS}

Analytical results of sorbent trap and SUMMA ${ }^{\mathrm{TM}, 2}$ canister tank air samples for selected inorganic gases and vapors are given in Table 3-1 in parts per million by volume (ppmv) in dry air. The concentration of water vapor given in Table 3-1 has been adjusted to tank conditions as given in Section 3.3. Inorganic analyte sorbent traps were prepared and analyzed by PNL, and SUMMA ${ }^{\text {TM }}$ canisters were analyzed for inorganic analytes by OGIST. Lucke et al. (1994) and Rasmussen (1994b) describe sample preparation and analyses.

Analyses of the VSS event inorganic vapor sorbent traps were performed within 20 days of sample collection, analyses of VSS event SUMMA ${ }^{\mathrm{TM}}$ canisters for inorganic compounds were performed 66 days after sample collection, and analyses of the ISS event hydrogen cyanide sorbent traps were performed 58 days after sample collection (Ligotke 1995). The solvent trap analyses satisfied the 60-day holding time requirement of the WHC quality assurance project plan (Keller 1994), but SUMMA ${ }^{\text {TM }}$ analyses did not. Though no holding time study has been performed to address the stability of compounds in SUMMA ${ }^{\text {MM }}$ canisters in the chemical matrix of the tank samples, these inorganic compounds (i.e., the permanent gases) would be expected to be very stable in the SUMMA ${ }^{T M}$ canisters, and the results may not have been affected even though the 60 day holding time requirement had been exceeded.

PNL results were produced at PNL quality assurance impact level 3. OGIST did not have a WHC-approved quality assurance project plan in place when performing analyses, so OGIST data have been placed in square brackets both in Table 3-1 and elsewhere in this report to indicate that they represent secondary results.

\subsection{Ammonia, Hydrogen, and Nitrous Oxide}

Ammonia concentration in the headspace of tank BY-106 was measured to be 74 ppmv. Ammonia concentrations at this level are not uncommon in the waste tank headspaces, and are known to as high as about 1040 ppmv in tank BY-108 (McVeety et al. 1995). Given the LFL of ammonia in air is about $15 \%$ by volume (vol\%), the measured $74 \mathrm{ppmv}$ corresponds to less than $0.05 \%$ of the LFL, and does not contribute appreciably to the flammability of the headspace.

The concentration of hydrogen was determined to be an average of [45.5 ppmv] in 3 SUMMA ${ }^{\text {TM }}$ canister samples from the May 1994 ISS event by OGIST (Rasmussen 1994a). Analysis by OGIST of the SUMMA ${ }^{\text {TM }}$ canister samples from the July 1994 VSS sampling event was problematic (Rasmussen 1994b). In general, hydrogen is of concern as a fuel. Given that the LFL for hydrogen in air is about $4 \mathrm{vol} \%$, the measured $45.5 \mathrm{ppmv}$ of hydrogen in tank BY-106, corresponds to only about $0.1 \%$ of the LFL. At this concentration, the hydrogen in tank BY-106 is not a flammability concern.

The nitrous oxide concentration in tank BY-106 was determined to be [70.6 ppmv] by OGIST. This is a typical concentration for nitrous oxide in the waste tanks that have been sampled. Under proper conditions, nitrous oxide can serve as an oxidizer to support combustion. However, Cashdollar et al. (1992) found that nitrous oxide had no significant effect on the flammability of hydrogen and air mixtures for hydrogen concentrations less than $20 \mathrm{vol} \%$, and that "small amounts of nitrous oxide (relative to air) do not appear to have much effect on the flammability". Their results suggest the measured nitrous oxide concentration is much too low to have a significant effect on the flammability of the tank BY-106 headspace.

2 SUMMA is a trademark of Molectrics, Inc., Cleveland, Ohio. 


\subsection{Carbon Dioxide and Carbon Monoxide}

The average measured headspace carbon dioxide concentration, [47.6 ppmv], is markedly lower than normal ambient air concentrations of about 350 to $400 \mathrm{ppmv}$. Carbon dioxide introduced by air exchange with the atmosphere is readily absorbed by caustic supernatant and interstitial liquids of the waste tanks, and converted to carbonate in solution. Though some tanks have sufficient waste carbonate concentrations to warrant above-ambient carbon dioxide concentrations, most do not, and consequently have below-ambient carbon dioxide concentrations in their headspaces.

Carbon monoxide in the tank BY-106 headspace, at about [0.45 ppmv], is more concentrated than in ambient air, where it typically is about 0.05 to 0.15 ppmv. Elevated waste tank headspace carbon monoxide concentrations are common, and are thought to be due to the decomposition of organic waste in the tanks. Carbon monoxide has not been measured at very high levels in any of the waste tanks, the highest level measured to date was [26.7 ppmv] in tank C-103 (Huckaby and Story 1994).

\subsection{Nitric Oxide, Nitrogen Dioxide, Water and Tritium}

Nitric oxide and nitrogen dioxide concentrations in the tank BY-106 headspace were determined to be 0.13 ppmv and $0.05 \mathrm{ppmv}$, respectively. These are both acid gases that would have very low equilibrium concentrations above the high pH interstitial liquid in tank BY-106. The measurable presence of nitric oxide is not uncommon in waste tank headspaces, and may be due to its formation from oxygen and nitrogen in the radiation field of the headspace. These constituents could potentially serve as oxidizers to support combustion, but at the measured concentrations would have a negligible effect on the flammability of the tank BY-106 headspace.

The water vapor concentration of tank BY-106 was determined to be about $14.7 \mathrm{mg} / \mathrm{L}$, at the tank headspace temperature of $27^{\circ} \mathrm{C}$ and pressure of $984 \mathrm{mbar}(740 \mathrm{torr})$, (WHC 1995b). This corresponds to water vapor partial pressure of $20.4 \mathrm{mbar}\left(15.3\right.$ torr), to a dew point of $17.8^{\circ} \mathrm{C}$, and to a relative humidity of $57 \%$.

Tritium was tested for using silica gel sorbent traps. It is assumed that tritium produced by the waste combines with hydroxide ions to form tritium-substituted water. Evaporation of the tritium-substituted water would then result in airborne radioactive contamination. Silica gel sorbent traps adsorb virtually all (normal and tritium-substituted) water vapor from the sampled tank air, and are analyzed at the WHC 222-S laboratory. Analysis of the silica gel, which would have trapped approximately $34 \mathrm{mg}$ of water vapor, indicated the total activity of the sample to be below the method detection limit of $50 \mathrm{pCi}$ (WHC 1995b).

\subsection{Hydrogen Cyanide}

Analysis of the hydrogen cyanide specific sorbent traps indicated the concentration of this analyte to be s $0.01 \mathrm{ppmv}$ in all 3 samples. The absence of hydrogen cyanide at measurable concentrations is consistent with the expectation that an acid gas, such as hydrogen cyanide, would not exist at significant concentrations above the caustic waste in tank BY-106. No hydrogen cyanide has been detected in any of the 10 waste tank headspaces sampled for this analyte.

\footnotetext{
${ }^{3}$ The carbon monoxide measurement in tank C-103 was made by Oregon Graduate Institute of Science and Technology, and placed in brackets to emphasize it should be considered secondary data.
} 


\subsection{Discussion of Inorganic Analytes}

Aside from water and carbon dioxide, the most abundant waste constituents in the tank BY-106 headspace are ammonia, nitrous oxide, and hydrogen. These have been detected in most tank headspaces sampled to date, and are usually the dominate waste species. The concentrations of each of these is about average for the passively ventilated tanks that have been sampled, with other values ranging roughly 1 order of magnitude higher and lower than those in tank BY-106. For comparison, inorganic compound results for tanks BY-104, BY-105, and BY-106 are given in Table 3-2.

The small relative standard deviations of the results, given in the last column in Table $3-1$, indicate the precision of reported results is very good. Relative standard deviations range from $1 \%$ for nitrous oxide results, to $28 \%$ for nitric oxide results. The larger relative standard deviation of the nitric oxide results is due to the fact that it is very near the analytical method's limit of quantitation. The precision reported depends both on sampling parameters (e.g., sample flow rate and flow time for sorbent traps) and analytical parameters (e.g., sample preparation, dilutions, etc.), and the small relative standard deviations suggest a high degree of control was maintained both in the field and in the laboratories.

As discussed briefly in Section 1.4, it is possible that gases and vapors generated by the waste in tanks BY104 and BY-105 could be transferred to tank BY-106 via the cascade lines. If significant exchange of selected inorganic gases and vapors were taking place between adjacent tanks, either their headspace compositions would be very similar (if the exchange was mutual), or all constituents detected in one tank would be at or equal or higher concentrations in the other tank (if air flowed predominantly from 1 tank to the other). Consideration of data in Table 3-2 suggests that tanks BY-105 and BY-106 have similar headspace compositions, and the potential transfer of air, gases, and vapors from tank BY-105 to tank BY106 can neither be proven nor ruled out. 


\subsection{ORGANIC VAPORS}

Organic vapors in the tank BY-106 headspace were sampled using SUMMATM canisters, which were analyzed at PNL, and triple sorbent traps (TSTs), which were analyzed by ORNL. None of the positively or tentatively identified organic analytes were at or above levels of concern. Both laboratories used a gas chromatograph (GC) equipped with a mass spectrometer (MS) detector to separate, identify, and quantitate the analytes. A quantitative measurement of the methane concentration and the total nonmethane organic carbon (TNMOC) concentration by the U.S. Environmental Protection Agency (EPA) task order 12 (TO-12) method was also performed by OGIST. Descriptions of sample device cleaning, sample preparations, and analyses are given by Jenkins et al. (1994), Lucke et al. (1994), and Rasmussen (1994b). No holding time study has been performed to determine the stability of analytes in SUMMA ${ }^{T M}$ canisters in the chemical matrix of the tank samples.

SUMMA ${ }^{\mathrm{TM}}$ sample results should be considered to be the primary organic vapor data for tank BY-106. These results were produced at PNL quality assurance impact level 3 , and all PNL analyses were completed 20 days after sample collection, well below the specified 60 day holding time (Keller 1994).

ORNL analyses of TST samples from this and other waste tanks generally agree with, support, and augment the SUMMA'M sample results. However, because certain WHC quality assurance requirements were not satisfied by ORNL, the quality assurance assessment of ORNL. by Hendrickson (1995) should be reviewed before results unique to the TST samples are used for decision making.

All TSTs prepared by ORNL had 3 surrogate compounds added to evaluate sample matrix effects, potential handling, storage, and shipment problems, and analytical instrumentation performance (Jenkins et al. 1995a). ORNL evaluated the surrogate recoveries using a statistical approach similar to that prescribed by SW 846 Method 8260A Volatile Organic Compounds by Gas Chromatography/Mass Spectrometry (GCMS) Capillary Column Technique (EPA 1992). Using this approach, ORNL reported that all surrogates had standard deviation values within the $95 \%$ confidence interval for variance, indicating that no bias was introduced in the measurement of analyte quantities (Jenkins 1995).

\subsection{Positively Identified Organic Analytes}

Positive identification of organic analytes using the methods employed by PNL and ORNL involves matching the GC retention times and MS data from a sample with that obtained by analysis of standards. The concentration of an analyte in the sample is said to be quantitatively measured if the response of the GCMS has been established at several known concentrations of that analyte (i.e., the GCMS has been calibrated for that analyte), and the MS response to the analyte in the sample is between the lowest and highest responses to the known concentrations (i.e., the analyte is within the calibration range).

ORNL and PNL. were assigned different lists of organic compounds, or target analytes, to positively identify and measure quantitatively. The ORNL target analyte list was derived from a review of the tank $\mathrm{C}-103$ headspace constituents by a panel of toxicology experts (Mahlum et al. 1994). The PNL target analyte list included 40 compounds in the Environmental Protection Agency (EPA) task order 14 (TO-14) method, which are primarily halocarbons and common industrial solvents (EPA 1988).

Table 4-1 lists the organic compounds positively identified and quantitated in SUMMA ${ }^{\mathrm{TM}}$ samples. Analysis for methane was performed by OGIST, all other analyses were performed by PNL. Only 7 of the 40 TO-14 analytes were observed to be above the 0.002 ppmv quantitation limit of the analyses. Averages reported are from analyses of 3 SUMMA ${ }^{\mathrm{TM}}$ canister samples except where noted. 


\section{WHC-SD-WM-ER-420 REV. 2}

Jenkins et al. (1994) report the positive identification of 26 of 27 analytes selected by WHC, (only 1 analyte, 1,1-dichloroethene, was below detection limits). Despite calibration of the instrument over about a 20-fold concentration range, 18 of the 24 compounds were outside of the calibration range in at least 1 of the 4 TST samples (i.e., these were not quantitated). The average concentrations of the positively identified compounds are given in Tables 4-2, 4-3, and 4-4. Table 4-2 lists the positively identified, quantitated analytes, Table 4-3 lists the positively identified analytes which were not quantitated, and Table 4-3 lists the positively identified analytes which exceeded their practical holding times. Tables 4-2, 4-3, and 4-4 are mutually exclusive, so that no analyte appears in more than 1 of these tables. Results in Tables 4-3 and 44 may not be accurate to within $\pm 30 \%$, as specified by Burnum (1995).

The ORNL practical holding time is defined as the holding time for which there is a $15 \%$ risk that the concentration of an analyte in the sample will be below its initial concentration. As indicated in Table 4-4, butanal and 1-butanol exceeded their practical holding times, and may have been affected by the 25 day period between sample collection and analysis (Jenkins 1995b). Jenkins et al. (1995) describe the ORNL practical holding time study, and report the practical holding times of butanal and 1-butanol are 1 and 17 days, respectively. It should be noted that the contractual holding time for the TST samples was 60 days.

Three analytes, dichloromethane, benzene, and toluene, were common to both the ORNL and PNL target lists. A comparison of the ORNL and PNL results for these analytes is given in Table 4-5. The ORNL and PNL results are in excellent agreement for dichloromethane and toluene, but differ by more than a factor of 3 for benzene.

The 3 most abundant organic compounds in the tank BY-106 headspace are methane, propanone, and 1butanol. At [3.6 ppmv], the methane concentration is about 2 times higher than its normal ambient air concentration. Methane is probably formed during the chemical and radiolytic degradation of organic wastes in the tank. Methane is not a constituent of toxicological concern, and its LFL in air is about 5 vol\%. The [3.6 ppmv] of methane in tank BY-106 consequently corresponds to about $0.007 \%$ of its LFL. Propanone, at $0.37 \mathrm{ppmv}$, and 1-butanol, at $0.34 \mathrm{ppmv}$, similarly present virtually no flammable or toxicological risks.

\subsection{Tentatively Identified Organic Analytes}

In addition to the target analytes, the ORNL and PNL analytical procedures allow the tentative identification of other organic compounds. Tentative identification of analytes was performed by comparing the MS molecular fragmentation patterns with a library of known MS fragmentation patterns. This method allows an organic analyte to be identified (with reasonable certainty) as an alkane, a ketone, an aldehyde, etc., and may also determine its molecular weight. The method usually does not, however, allow the unambiguous identification of structural isomers, and this ambigutity increases with analyte molecular weight. Using this. method, many analytes can be tentatively identified with reasonable confidence without having to inject each into the GC/MS to determine their GC retention times or specific MS patterns.

By the nature of the sampling devices, virtually all organic vapors present in the tank headspace are collected by both TST and SUMMA ${ }^{\text {TM }}$ samples. Analyses of the samples are designed to recover, separate, and identify the organic vapors in the samples. TSTs are not good for collecting highly volatile compounds (i.e., molecules more volatile than propane), but are quite good for most others. In contrast, the recovery of very low volatility compounds (e.g., molecules with more than about 15 carbon atoms) and some polar compounds with moderate volatility (e.g., butanal) from SUMMA ${ }^{\mathrm{TM}}$ samples has been problematic.

The organic compounds tentatively identified in SUMMA ${ }^{T M}$ canister samples by PNL are listed, with their estimated concentrations, in Table 4-6. Compounds are listed in Table 4-6 in the order by which they 


\section{WHC-SD-WM-ER-420 REV. 2}

eluted chromatographically, and only non-zero results are included in the reported averages. The list of tentatively identified compounds defected in TST samples, and their estimated concentrations, is given in Table 4-7. Compounds are listed in Table 4-7 according to the order by which the eluted chromatographically. The averages reported by ORNL in Table 4-7 are all 4-sample averages, and if an analyte was not detected in a sample, its concentration in that sample was considered to be zero for averaging purposes. Estimated concentrations are in $\mathrm{mg} / \mathrm{m}^{3}$, based on dry air at $0{ }^{\circ} \mathrm{C}$ and 1.01 bar.

Because the list of tentatively identified organic compounds in TST samples is particularly long and locating any given compound may be difficult, the list has been sorted alphanumerically by compound name in Table 4-8. Table 4-9 gives the same list, sorted in order of decreasing estimated concentration. Numbers in the first columns of Tables 4-8 and 4-9 (Cmpd \#) identify the location of the compound in Table 4-7.

The ORNL and PNL methods used to tentatively identify and estimate concentrations are described by Jenkins et al. (1994) and Pool et al. (1995), respectively, and should be reviewed before this data is used for decision making. Concentrations given in Tables 4-6 through 4-9 should be considered rough estimates. Results in these tables are presented in terms of obsenved peaks, and are not adjusted for the occurrence of split chromatographic peaks (e.g., Cmpd \# 2,3, and 4 in Table 4-7). In these instances, the estimated concentration of a compound appearing as a doublet or triplet is simply the sum of the individual peak estimates.

\subsection{Total Nonmethane Organic Carbon}

OGIST measured the TNMOC concentration in 3 SUMMATM canister samples using the EPA TO-12 method (Rasmussen 1994b). The sample mean was $\left[9,900 \mu \mathrm{g} / \mathrm{m}^{3}\right]$, with a standard deviation of $\left[350 \mu \mathrm{g} / \mathrm{m}^{3}\right]$. This value is neither high nor low compared to most other waste tanks sampled to date.

\subsection{Discussion of Organic Analytes}

Some of the compounds listed in Tables 4-1 through 4-9 were introduced to the tank with process waste streams, and are detected in the headspace because the original inventory has not been completely evaporated or degraded. Examples of these are tributyl phosphate, which was used as an extractant in several Hanford processes; dibutyl butylphosphonate, which was a contaminant of tributyl phosphate; and the semivolatile normal paraffinic hydrocarbons (NPHs), (i.e., n-undecane, n-dodecane, n-tridecane, ntetradecane, and n-pentadecane) and branched and cyclic alkanes (e.g., methylated decahydronaphthalenes, cyclopentanes, and cyclohexanes) with similar boiling points that were used as diluents for tributyl phosphate. The specific presence of the decahydronaphthalenes and cyclohexanes, which are not observed in alf tanks with high NPH concentrations, is an indication of their different waste histories.

Most of the compounds in Tables 4-1 through 4-9, however, are believed to be chemical reaction and radiolytic reaction products of the semivolatile or nonvolatile organic waste stored in the tank. Specifically, 1-butanol is known to be formed by the hydrolysis of tributyl phosphate, and it thought that the alcohols, aldehydes, ketones, nitriles, alkenes, and short chain alkanes are all degradation products of NPHs.

Examination of the compounds listed in Tables 4-1 through 4-9 suggests many of the volatile species (presumed to be degradation products of the NPHs) have functional groups on the molecule's first or second carbon atom. For example, most alkenes listed have their double bond between the first and second carbon atoms, and ketones generally have the double bonded oxygen atom on the second carbon atom. 
WHC-SD-WM-ER-420 REV. 2

As observed in other NPH-containing waste tanks, there are many small cyclic compounds, specifically cyclopropanes, cyclopentanes, and furans. The presence of these suggest that organic radicals, formed in the radiation field of the tank, play a role in the degradation of the semivolatile compounds. 


\subsection{SUMMARY}

The tank BY-106 headspace was sampled in May 1994 and July 1994 for gases and vapors to address flammability and industrial hygiene concerns. Results unique to the May 1994 event and essentially all results from the July 1994 event have been reported. It was determined that no headspace constituents exceeded the flammability or industrial hygiene notification limits specified in the current Vapor Sampling and Analysis Plan (Homi 1995). 
'.

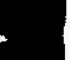


WHC-SD-WM-ER-420 REV. 2

\subsection{REFERENCES}

29 CFR 1910.120, 1993, "Hazardous Waste Operations and Emergency Response", Code of Federal Regulations.

Burnum, S. T., 1995, Qualiification of Reported WHC Vapor Program Data, (letter 95-CHD-065 to president, Westinghouse Hanford Company, August 18), Department of Energy, Richland Operations Office, Richland, Washington.

Cashdollar, K. L..,M. Hertzberg, I. A. Zlochower, C. E. Lucci, G. M. Green, and R. A. Thomas, 1992, Laboratory Flammability Studies of Mixtures of Hydrogen, Nitrous Oxide, and Air, WHC-SD-WMES-219 Rev. 0, Westinghouse Hanford Company, Richland, Washington.

Dougherty, L. F., 1995, Single Shell Tank Interim Operational Safety Requirements, WHC-SD-WM-OSR005 Rev. 0, Westinghouse Hanford Company, Richland, Washington.

EPA 1988, Compendium of Methods for the Determination of Toxic Organic Compounds in Ambient Air, PB90-127374, U.S. Environmental Protection Agency, Washington, D.C.

EPA 1992, Test Methods for Evaluating Solid Waste, SW-846 Rev. 1, U.S. Environmental Protection Agency, Washington, D.C.

Farley, W. G., 1991, Safety Assessment for Gas Sampling All Ferrocyanide Tanks, WHC-SD-WM-SAD-009 Rev. 2, Westinghouse Hanford Company, Richland, Washington.

Hendrickson, R. W., 1995, Tank Vapor Characterization Oak Ridge National Laboratories Quality Assurance Assessment, TWRSQA-95-0012, Westinghouse Hanford Company, Richland, Washington.

Homi, C. S., 1995, Vapor Sampling and Analysis Plan, WHC-SD-WM-TP-335 Rev. OG, Westinghouse Hanford Company, Richland, Washington.

Huckaby, J. L., 1994a, Vapor Sampling System (VSS) and In Situ Sampling (ISS) Method Comparison, WHC-SD-WM-RPT-101 Rev. 0, Westinghouse Hanford Company, Richland, Washington.

Huckaby, J. L., 1994b, Tank 241-C-103 Headspace Flammability, WHC-EP-0734 Rev. 1, Westinghouse Hanford Company, Richland, Washington.

Huckaby, J. L., H. Babad, and D. R. Bratzel, 1995, Headspace Gas and Vapor Characterization Summary for the 43 Vapor Program Suspect Tanks, WHC-SD-WM-ER-514 Rev. 0, Westinghouse Hanford Company, Richland, Washington.

Huckaby, J. L., and D. R. Bratzel, 1995a, Tank 241-BY-104 Headspace Gas and Vapor Characterization Results for Samples Collected in April 1994 and June 1994, WHC-SD-WM-ER-418, Rev. 1, Westinghouse Hanford Company, Richland, Washington.

Huckaby, J. L., and D. R. Bratzel, 1995b, Tank 241-BY-105 Headspace Gas and Vapor Characterization Results for Samples Collected in May 1994 and July 1994, WHC-SD-WM-ER-419, Rev. 1, Westinghouse Hanford Company, Richland, Washington 


\section{WHC-SD-WM-ER-420 REV. 2}

Huckaby, J. L., and M. S. Story, 1994, Vapor Characterization of Tank 241-C-103, WHC-EP-0780 Rev. 0, Westinghouse Hanford Company, Richland, Washington.

Jenkins, R. A., 1995a, Untitled, (Letter 090195A to D. Brazzel, September 1), Oak Ridge National Laboratory, Oak Ridge, Tennessee

Jenkins, R. A., 1995b, Untitled, (Letter 091495A to D. Bratzel, September 14), Oak Ridge National Laboratory, Oak Ridge, Tennessee.

Jenkins, R. A, A. B. Dindal, C. E. Higgins, C. Y. Ma, and J. T. Skeen, 1994, Analaysis of Tank 241-BY-106 Headspace Components, Oak Ridge National Laboratory, Oak Ridge, Tennessee.

Jenkins, R. A, A. B. Dindal, C. Y. Ma, M. A. Palausky, J. T. Skeen, and C. K. Bayne, 1995b, Analysis of Tank 241-TY-104 Headspace Components, ORNL-CASD-FR-241TY104.95 Rev. 1, Oak Ridge National Laboratory, Oak Ridge, Tennessee.

Keller, K. K., 1994, Quality Assurance Project Plan for Tank Vapor Characterization, WHC-SD-WM-QAPP013 Rev. 2, Westinghouse Hanford Company, Richland, Washington.

Ligotke, M. W., 1995, PNL. Vapor Project Analytical Holding Times, (Letter to D. R. Bratzel, September 23 , 1995) Pacific Northwest Laboratory, Richland, Washington.

Lucke, R. B., K. H. Pool, M. W. Ligotke, T. W. Clauss, B. D. MoVeety, J. S. Fruchter, and S. C. Goheen, 1994, Vapor Space Characterization of Waste Tank 241-BY-106: Results from Samples Collected Through the Vapor Sampling System on 7/8/94, PNL-10248 UC-606, Pacific Northwest Laboratory, Richland, Washington.

Mahlum, D. D., J. Y. Young, and R. E. Weller, 1994, Toxicologic Evaluation of Analytes from Tank 231-C103, PNL-10189, Pacific Northwest Laboratory, Richland, Washington.

Mahon, R., 1995, FY 1994 lin-Situ Sampling System Summary Report, (Letter OM624-95-055 to Bratzel), Westinghouse Hanford Company, Richland, Washington.

McVeety, B. D., T. W. Clauss, M. W. Ligotke, K. H. Pool, R. B. Lucke, G. S. Klinger, J. S. Young, M. McCulloch, J. S. Fruchter, and S. C. Goheen, 1994, Vapor Space Characterization of Waste Tank 241-BY-108; Results from Samples Collected on 10/27/94, PNL-10495, UC-606, Pacific Northwest Laboratory, Richland, Washington.

Meacham, J. E., H. Babad, R. J. Cash, G. T. Dukelow, S. J. Eberlein, D. W. Hamilton, G. D. Johnson, J. W. Osborne, M. A. Payne, D. J. Sherwood, D. A. Turner, and J. L. Huckaby, 1995, Approach for Tank Safety Characterization of Hanford Site Waste, WHC-EP-0843 Rev. 0, UC-2070, Westinghouse Hanford Company, Richland, Washington.

NFPA 1992, Standard on Explosion Prevention Systems, NFPA 69, National Fire Protection Association, Quincy, Massachusetts.

Osborne, J. W., and J. L. Huckaby, 1994, Program Plan for the Resolution of Tank Vapor /ssues, WHC-EP. 0562 Rev. 1, Westinghouse Hanford Company, Richland, Washington. 
Osborne, J. W., J. L. Huckaby, T. P. Rudolph, E. R. Hewitt, D. D. Mahlum, J. Y. Young, and C. M. Anderson, 1994, Data Quality Objectives for Generic In-Tank Health and Safety Issue Resolution, WHC-SD-WM-DQO-002, Westinghouse Hanford Company, Richland, Washington.

Pingel, L. A., 1994, Results from the In-Situ Vapor Sampling of Waste Tank BY-106, (Internal memorandum 8E920-SAS94-090 to J. L. Huckaby, May 25), Westinghouse Hanford Company, Richland, Washington.

Pool, K. H, M. W. Ligotke, T. W. Clauss, R. B. Lucke, B. D. McVeety, M. McCulloch, J. S. Fruchter, and S. C. Goheen, 1995, Vapor Space Characterization of Waste Tank 241-BY-106 (In Situ): Results from Samples Collected on 5/4/94 and 5/5/94, PNL-10284 UC-606, Pacific Northwest Laboratory, Richland, Washington.

Rasmussen, R. A., 1994a, Air Samples Collected at Waste Tanks: BY-103, BY-104, BY-105, BY-106, BY111 by Westinghouse Hanford in 6-L SS SUMMA@ Canisters, Oregon Graduate Institute of Science and Technology, Beaverton, Oregon.

Rasmussen, R. A., 1994b, Air Samples Collected at Waste Tank 241-BY-106 on July 8, 1994 by Westinghouse Hanford in 6-L SS SUMMA@ Canisters, Oregon Graduate Institute of Science and Technology, Beaverton, Oregon.

WHC 1995a, Operating Specifications for Watchlist Tanks, OSD-T-151-00030, Rev. B-9, Westinghouse Hanford Company, Richland, Washington

WHC 1995b, Sampling Report for the Vapor and Gas Sampling of Tank 241-BY-106 Using the Vapor Sampling System, WHC-SD-WM-RPT-109, Westinghouse Hanford Company, Richland, Washington. 


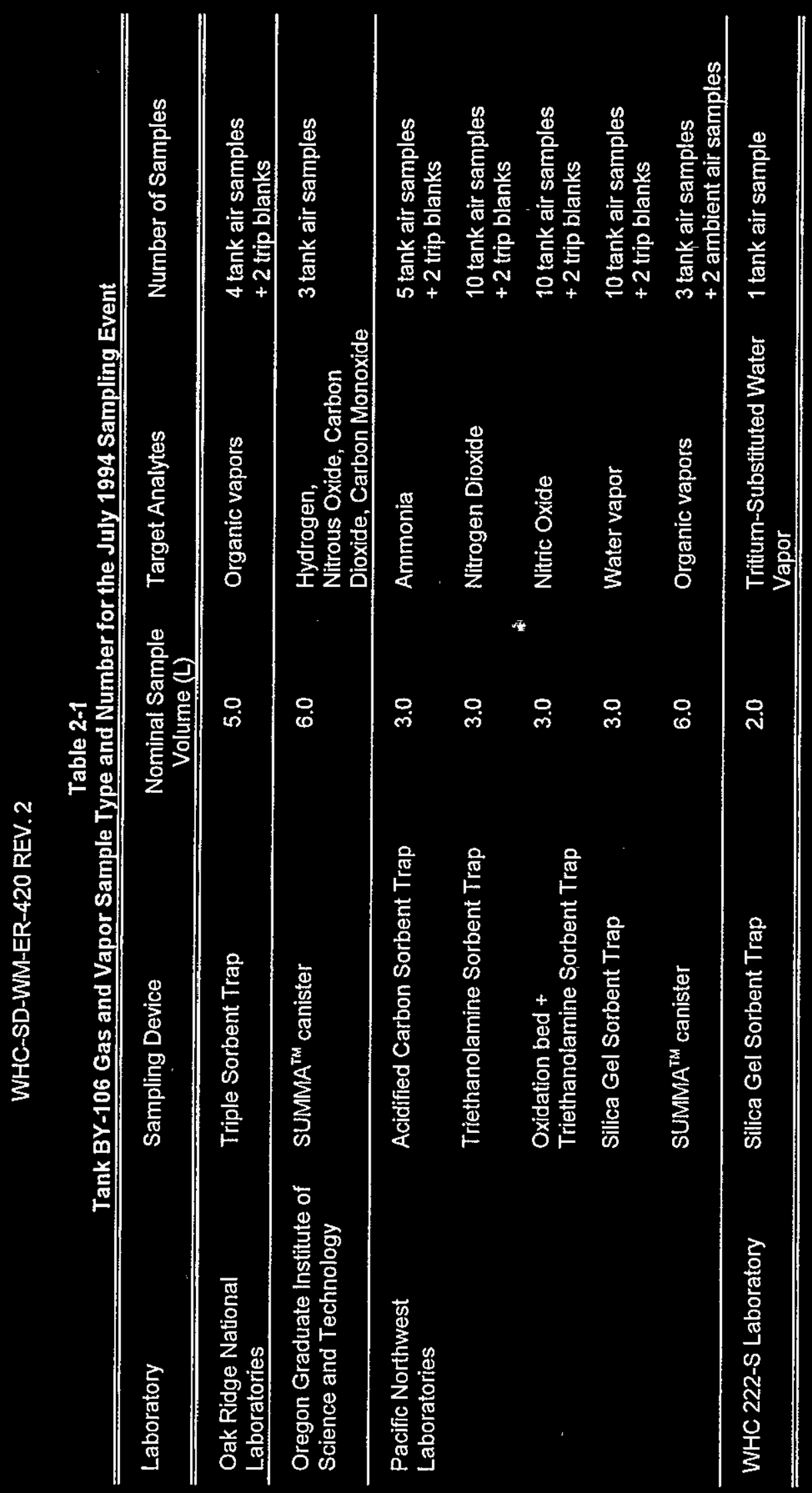




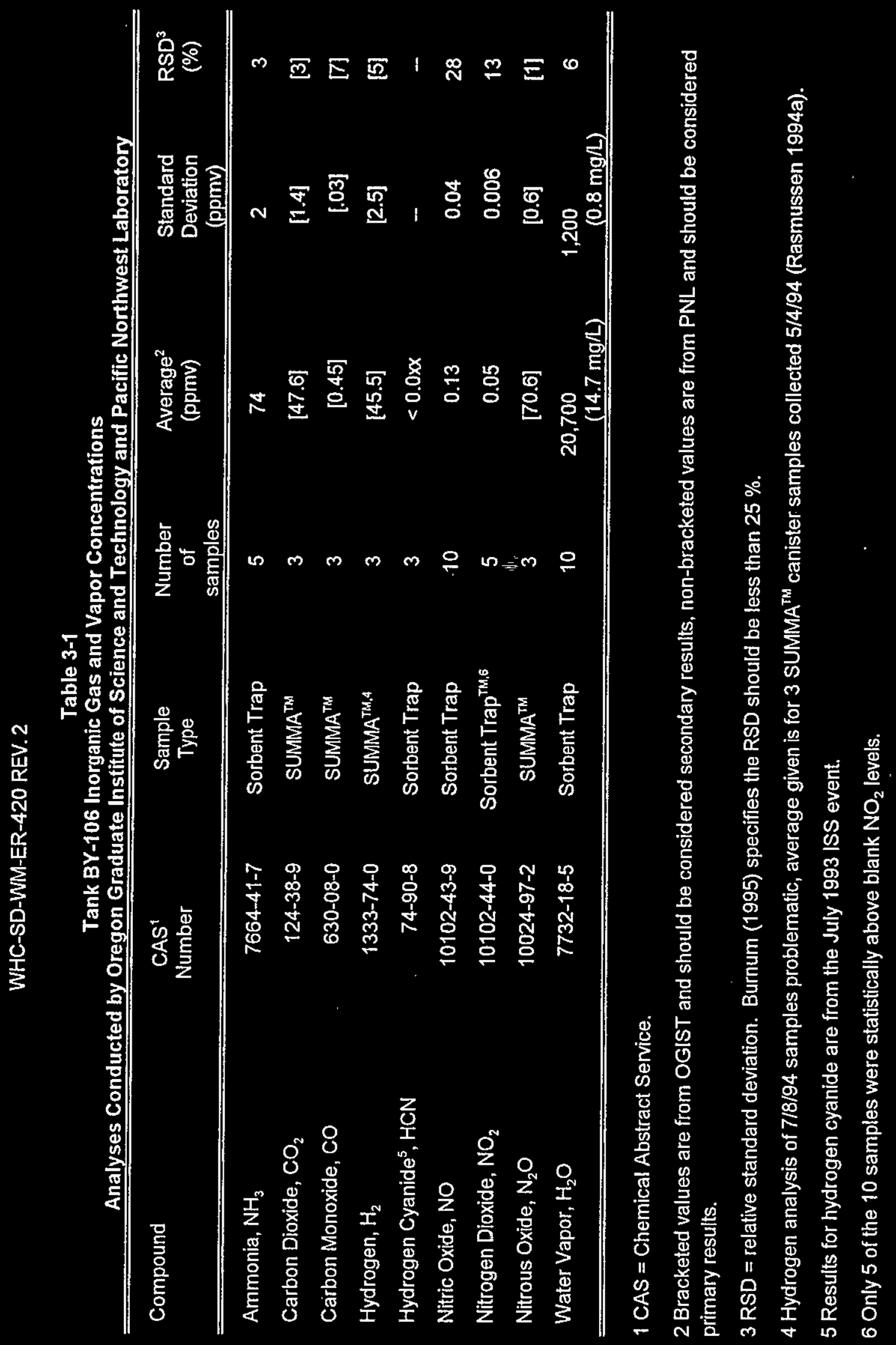




\section{Table 3-2}

Comparison of Tank BY-104, BY-105, and BY-106 Headspace Constituents -Inorganic Analyses by Oregon Graduate Institute of Science and Technology, and Organic Analyses by Oak Ridge National Laboratory'

\begin{tabular}{|c|c|c|c|}
\hline Tank: & BY $-104^{2}$ & $B Y-105^{3}$ & BY-106 \\
\hline Date sampled, (mo/day/yr) & $6 / 24 / 94$ & $7 / 7 / 94$ & $7 / 8 / 94$ \\
\hline Headspace temperature, $\left({ }^{\circ} \mathrm{C}\right)$ & 26 & 26 & 27 \\
\hline Ammonia, (ppmv) & 248 & 43 & 74 \\
\hline Hydrogen, (ppmv) & [295] & [47.9] & [45.5] \\
\hline Carbon dioxide, (ppmv) & [10.5] & [94] & [47.6] \\
\hline Carbon monoxide, (ppmv) & {$[1.0]$} & {$[0.38]$} & {$[0.45]$} \\
\hline Nitric oxide, (ppmv) & 0.29 & 0.10 & 0.13 \\
\hline Nitrogen dioxide, (ppmv) & $=0.07$ & $=0.02$ & 0.05 \\
\hline Nitrous oxide, (ppmv) & [201] & [49.5] & [70.6] \\
\hline Water vapor, $\left(\mathrm{mg} / \mathrm{m}^{3}\right)$ & 14.1 & 14.9 & 14.7 \\
\hline Water vapor, (\% relative humidity) & 58 & 76 & 57 \\
\hline Ethanenitrile (acetonitrile), (ppmv) & $(0.33)$ & $(0.081)$ & $(0.12)$ \\
\hline Propanone (acetone), (ppmv) & $(1.2)$ & $(0.25)$ & $(0.37)$ \\
\hline 1-Butanol, (ppmv) & $(1.0)$ & $(0.70)$ & $(0.34)$ \\
\hline n-Dodecane, (ppmv) & $(0.058)$ & $\cdot(0.0081)$ & $(0.0065)$ \\
\hline n-Tridecane, (ppmv) & $(0.084)$ & $(0.010)$ & $(0.0069)$ \\
\hline Total nonmethane organic carbon, $\left(\mathrm{mg} / \mathrm{m}^{3}\right)$ & {$[60.8]$} & {$[12.7]$} & {$[9.9]$} \\
\hline
\end{tabular}

1 Where PNL inorganic gas or vapor data was unavailable, OGIST results are given. OGIST results are in brackets to indicate the data should be considered secondary results. Organic vapor results are from ORNL, with non-quantitative values in parentheses and quantitative values not in parentheses.

2 Data are from Huckaby and Bratzel 1995a.

3 Data are from Huckaby and Bratzel 1995b. 
Table 4-1

Tank BY-106 Quantitatively Measured Organic Compounds in SUMMA ${ }^{\mathrm{TM}}$ Samples Analyses by Pacific Northwest Laboratory

\begin{tabular}{|c|c|c|c|c|c|}
\hline$\underset{\#}{\text { Cmpd }}$ & Compound & $\begin{array}{l}\mathrm{CAS}^{4} \\
\text { Number }\end{array}$ & $\begin{array}{l}\text { Average }^{5} \\
\text { (ppmv) }\end{array}$ & $\begin{array}{c}\text { Standard } \\
\text { Deviation } \\
\text { (ppmy) }\end{array}$ & $\begin{array}{c}\mathrm{RSD}^{6} \\
(\%)\end{array}$ \\
\hline 1 & Methane 7 & $74-82-8$ & [3.6] & {$[<0.1]$} & [4] \\
\hline 2 & Dichlorodifluoromethane & $75-71-8$ & 0.011 & 0.002 & 18 \\
\hline 3 & Chloromethane (Methyl chloride) & $74-87-3$ & 0.0028 & 0.0006 & 20 \\
\hline 4 & Trichlorofluoromethane & $75-69-4$ & 0.19 & 0.02 & 9 \\
\hline 5 & $\begin{array}{l}\text { Dichloromethane (Methylene } \\
\text { chloride) }\end{array}$ & $75-09-2$ & $<0.002$ & - & - \\
\hline 6 & Benzene & $71-43-2$ & 0.0022 & 0.0004 & 19 \\
\hline 7 & Toluene & $108-88-3$ & 0.0071 & 0.0003 & 5 \\
\hline 8 & Tetrachloroethene & $127-18-4$ & 0.003 & 0.001 & 34 \\
\hline 9 & Ethylbenzene & $100-41-4$ & $0.0013^{8}$ & - & - \\
\hline 10 & $\begin{array}{l}\text { 1,3-Dimethylbenzene (m-xylene })+ \\
\text { 1,4-Dimethylbenzene }(p-x y l e n e)\end{array}$ & $\begin{array}{l}108-38-3 \\
106-42-3\end{array}$ & 0.0031 & 0.0004 & 13 \\
\hline
\end{tabular}

$4 \mathrm{CAS}=$ Chemical Abstract Service.

5 Average of 3 samples.

6 RSD = relative standard deviation. Burnum (1995) specifies the RSD should be less than $25 \%$.

7 Methane analyses were performed by OGIST and should be considered a secondary result (Ramussen 1994a).

8 Result of single sample, other samples $<0.002 \mathrm{ppmv}$. 
WHC-SD-WM-ER-420 REV. 2

Table 4-2

Tank BY-106 Quantitatively Measured Organic Compound Average Concentrations Analyses by Oak Ridge National Laboratory'

\begin{tabular}{clcccc}
\hline $\begin{array}{c}\text { Cmpd } \\
\#\end{array}$ & Compound & $\begin{array}{c}\text { CAS }^{2} \\
\text { Number }\end{array}$ & $\begin{array}{c}\text { Average }^{3} \\
\text { (ppmv) }\end{array}$ & $\begin{array}{c}\text { Standard } \\
\text { Deviation } \\
\text { (ppmv) }\end{array}$ & $\begin{array}{c}\mathrm{RSD}^{4} \\
(\%)\end{array}$ \\
\hline \hline 1 & Propanenitrile & $107-12-0$ & 0.0043 & 0.0002 & 5 \\
2. & Benzene & $71-43-2$. & 0.0073 & 0.0008 & 11 \\
3 & Toluene & $108-88-3$ & 0.0083 & 0.0011 & 13 \\
4 & 2-Hexanone & $591-78-6$ & 0.0042 & 0.0005 & 13 \\
5 & 2-Heptanone & $110-43-0$ & 0.0032 & 0.0007 & 23 \\
6 & n-Nonane & $111-84-2$ & 0.0046 & 0.0006 & 14 \\
\hline \hline
\end{tabular}

1 Results in this table are quantitative (as defined in Section 4.1).

$2 \mathrm{CAS}=$ Chemical Abstract Service.

3 Average of 4, 5-L TST samples.

4 RSD = relative standard deviation. Burnum (1995) specifies the RSD should be less than $25 \%$. 
WHC-SD-WM-ER-420 REV. 2

Table 4-3

Tank BY-106 Positively Identified Organic Compounds in TST Samples Analyses by Oak Ridge National Laboratory

\begin{tabular}{clcccc}
\hline $\begin{array}{c}\text { Cmpd } \\
\#\end{array}$ & Compound & $\begin{array}{c}\text { CAS }^{2} \\
\text { Number }\end{array}$ & $\begin{array}{c}\text { Average } \\
\text { (ppmv) }\end{array}$ & $\begin{array}{c}\text { Standard } \\
\text { Deviation } \\
\text { (ppmv) }\end{array}$ & $\begin{array}{c}\text { RSD }^{4} \\
(\%)\end{array}$ \\
\hline 1 & $\begin{array}{l}\text { Dichloromethane } \\
\text { (methylene chloride) }\end{array}$ & $75-09-2$ & 0.00047 & 0.00017 & 36 \\
2 & Ethanenitrile (acetonitrile) & $75-05-8$ & 0.12 & 0.02 & 16 \\
3 & Propanone (acetone) & $67-64-1$ & 0.37 & 0.08 & 23 \\
4 & n-Hexane & $110-54-3$ & 0.085 & 0.011 & 13 \\
5 & n-Butanenitrile & $109-74-0$ & 0.0015 & 0.00009 & 6 \\
6 & 2-Pentanone & $107-87-9$ & 0.011 & 0.0009 & 9 \\
7 & n-Heptane & $142-82-5$ & 0.031 & 0.002 & 6 \\
8 & n-Pentanenitrile & $110-59-8$ & 0.0010 & 0.0001 & 11 \\
9 & n-Octane & $111-65-9$ & 0.012 & 0.001 & 11 \\
10 & n-Hexanenitrile & $628-73-9$ & 0.00072 & 0.00011 & 15 \\
11 & n-Heptanenitrile & $629-08-3$ & 0.00034 & 0.00003 & 9 \\
12 & 2-Octanone & $111-13-7$ & 0.00094 & 0.00029 & 31 \\
13 & n-Octanenitrile & $124-12-9$ & 0.00018 & 0.00002 & 9 \\
14 & n-Nonanenitrile & $2243-27-8$ & 0.00019 & 0.00003 & 15 \\
15 & n-Dodecane & $112-40-3$ & 0.0065 & 0.0014 & 22 \\
16 & n-Tridecane & $629-50-5$ & 0.0069 & 0.0019 & 28 \\
17 & Tributyl phosphate & $126-73-8$ & 0.000044 & 0.000009 & 20 \\
18 & Dibutyl butylphosphonate & $78-46-6$ & 0.0000064 & 0.0000030 & 47 \\
\hline \hline
\end{tabular}

1 Results in this table are not quantitative (as defined in Section 4.1 ) because measured values in at least 1 of the samples are outside instrument calibration limits.

$2 \mathrm{CAS}=$ Chemical Abstract Service.

3 Average of 4, 5-L TST samples.

$4 \mathrm{RSD}=$ relative standard deviation. Burnum (1995) specifies the RSD should be less than $25 \%$. 


\section{Table 4-4}

Tank BY-106 Positively Identified Compounds in TST Samples for which Practical Holding Times were Exceeded -Analyses by Oak Ridge National Laboratory'

\begin{tabular}{clcccc}
\hline \hline $\begin{array}{c}\text { Cmpd } \\
\#\end{array}$ & Compound & $\begin{array}{c}\mathrm{CAS}^{2} \\
\text { Number }\end{array}$ & $\begin{array}{c}\text { Average } \\
(\mathrm{ppmv})\end{array}$ & $\begin{array}{c}\text { Standard } \\
\text { Deviation } \\
\text { (ppmv) }\end{array}$ & $\begin{array}{c}\mathrm{RSD}^{4} \\
\text { (\%) }\end{array}$ \\
\hline \hline 1 & Butanal $^{5}$ & $123-72-8$ & 0.061 & 0.013 & 21 \\
2 & $1-$ Butanol $^{5}$ & $71-36-3$ & 0.34 & 0.03 & 8 \\
\hline \hline
\end{tabular}

1 Practical holding times are defined and discussed in Section 4.1.

$2 \mathrm{CAS}=$ Chemical Abstract Service.

3 Average of 4, 5-L TST samples.

$4 \mathrm{RSD}=$ relative standard deviation. Burnum (1995) specifies the RSD should be less than $25 \%$.

5 The concentration of this analyte was not quantitatively measured (as defined in Section 4.1), because the measured concentration was outside of the instrumental calibration limits. 
WHC-SD-WM-ER-420 REV. 2

Table 4-5

Tank BY-106 Comparison of Organic Compounds in TST and SUMMA ${ }^{\text {TM }}$ Samples Analyses by Pacific Northwest Laboratory and Oak Ridge National Laboratory

\begin{tabular}{clcccc}
\hline \hline $\begin{array}{c}\text { Cmpd } \\
\#\end{array}$ & Compound & $\begin{array}{c}\text { CAS }^{1} \\
\text { Number }\end{array}$ & $\begin{array}{c}\text { TST } \\
\text { Average }^{2} \text { (ppmv) }\end{array}$ & $\begin{array}{c}\text { SUMMA }^{\text {TM }} \\
\text { Average }^{3} \\
\text { (ppmv) }\end{array}$ & $\begin{array}{c}\text { PRD }^{4} \\
(\%)\end{array}$ \\
\hline \hline 1 & $\begin{array}{l}\text { Dichloromethane } \\
\text { (Methylene chloride) }\end{array}$ & $75-09-2$ & 0.00047 & $<0.002$ & - \\
2 & $\begin{array}{l}\text { Benzene } \\
3\end{array}$ & $71-43-2$ & 0.0073 & 0.0022 & 107 \\
\hline \hline
\end{tabular}

$1 \mathrm{CAS}=$ Chemical Abstract Service .

2 Average of 4, 5-L TST samples analyses.

3 Average of 3 samples analyses.

$4 \mathrm{PRD}=$ percent relative difference. Keller (1994) requires the PRD to be less than $20 \%$. 
WHC-SD-WM-ER-420 REV. 2

Table 4-6

Tank BY-106 Tentatively Identified Organic Compounds in SUMMA ${ }^{\text {TM }}$ Samples Analyses by Pacific Northwest Laboratory

\begin{tabular}{|c|c|c|c|c|}
\hline Cmpd \# & Compound & $\begin{array}{c}\mathrm{CAS}^{1} \\
\text { Number }\end{array}$ & $\begin{array}{l}\text { Average }^{5} \\
\left(\mathrm{mg} / \mathrm{m}^{3}\right)\end{array}$ & $\begin{array}{c}\text { Standard }{ }^{2} \\
\text { Deviation } \\
\left(\mathrm{mg} / \mathrm{m}^{3}\right) \\
\end{array}$ \\
\hline 1 & Propene & $115-07-1$ & 1.04 & 0.18 \\
\hline 2 & Propane & $74-98-6$ & 0.68 & 0.14 \\
\hline 3 & Propyne & $74-99-7$ & 0.06 & 0.01 \\
\hline 4 & Cyclopropane & $75-19-4$ & 0.17 & 0.04 \\
\hline 5 & 2-Methylpropane & $75-28-5$ & 0.56 & 0.24 \\
\hline 6 & 2-Methylpropene & $115-11-7$ & 0.73 & 0.27 \\
\hline 7 & n-Butane & $106-97-8$ & 0.86 & 0.35 \\
\hline 8 & 2-Butene & $107-01-7$ & 0.16 & 0.07 \\
\hline 9 & Ethanol ${ }^{3}$ & $64-17-5$ & 0.11 & - \\
\hline 10 & C4 Alkene & & 0.09 & 0.04 \\
\hline 11 & Acetone & $67-64-1$ & 0.88 & 0.46 \\
\hline 12 & C5 Alkane ${ }^{4}$ & & 0.40 & 0.24 \\
\hline 13 & 1-Pentene & $109-67-1$ & 0.25 & 0.11 \\
\hline 14 & n-Pentane & $109-66-0$ & 0.75 & 0.44 \\
\hline 15 & C5 Alkene $^{3}$ & & 0.06 & - \\
\hline 16 & C6 Alkene ${ }^{3}$ & & 0.08 & -- \\
\hline 17 & 1-Pentanol $\left.\right|^{3}$ & $71-41-0$ & 0.07 & - \\
\hline 18 & 2-Methylpentane & $107-83-5$ & 0.71 & 0.06 \\
\hline 19 & Butanal & $123-72-8$ & 0.17 & 0.04 \\
\hline 20 & 2-Butanone (MEK) & $78-93-3$ & 0.17 & 0.03 \\
\hline 21 & 3-Methylpentane & $96-14-0$ & 0.14 & 0.01 \\
\hline 22 & 1-Hexene & $592-41-6$ & 0.15 & 0.02 \\
\hline 23 & n-Hexane & $110-54-3$ & 0.54 & 0.08 \\
\hline 24 & Tetrahydrofuran & $109-99-9$ & 0.17 & 0.02 \\
\hline 25 & 2-Methyl-1-pentene & $763-29-1$ & 0.07 & 0.01 \\
\hline 26 & 1-Butanol & $71-36-3$ & 0.99 & 0.13 \\
\hline 27 & 2.Pentanone & $107-87-9$ & 0.13 & 0.02 \\
\hline
\end{tabular}


WHC-SD-WM-ER-420 REV. 2

\begin{tabular}{|c|c|c|c|c|}
\hline Cmpd \# & Compound & $\begin{array}{c}\mathrm{CAS}^{\prime} \\
\text { Number }\end{array}$ & $\begin{array}{l}\text { Average }^{5} \\
\left(\mathrm{mg} / \mathrm{m}^{3}\right)\end{array}$ & $\begin{array}{r}\text { Standard }{ }^{2} \\
\text { Deviation } \\
\left(\mathrm{mg} / \mathrm{m}^{3}\right)\end{array}$ \\
\hline 28 & C7 Alkane & & 0.24 & 0.05 \\
\hline 29 & 1-Heptene & $592-76-7$ & 0.06 & 0.01 \\
\hline 30 & n-Heptane & $142-82-5$ & 0.33 & 0.04 \\
\hline 31 & C7 Alkene & & 0.06 & 0.01 \\
\hline 32 & C8 Alkane & & 0.12 & 0.02 \\
\hline 33 & Hexanal $^{3}$ & $66-25-1$ & 0.07 & - \\
\hline 34 & n-Octane & $111-65-9$ & 0.11 & 0.02 \\
\hline 35 & 2-Butoxyethanol ${ }^{3}$ & $111-76-2$ & 0.06 & - \\
\hline 36 & C10 Alkane & & 0.06 & 0.01 \\
\hline 37 & C10 Alkane Al $^{3}$ & & 0.05 & - \\
\hline 38 & Pheno $^{3}$ & $108-95-2$ & 0.05 & - \\
\hline 39 & C11 Alkane ${ }^{3}$ & & 0.05 & -- \\
\hline 40 & n-Undecane & $1120-21-4$ & 0.06 & 0.00 \\
\hline 41 & n-Dodecane & $112-40-3$ & 0.09 & 0.01 \\
\hline 42 & C12 Alkane & & 0.07 & 0.01 \\
\hline 43 & Benzothiazole ${ }^{3}$ (impurity) & $95-16-9$ & 0.06 & - \\
\hline 44 & C7 Cyclohexane ${ }^{3}$ & & 0.06 & - \\
\hline 45 & C13 Alkane & & 0.06 & 0.01 \\
\hline 46 & $\mathrm{n}$-Tridecane & $629-50-5$ & 0.09 & 0.01 \\
\hline 47 & C13 Alkane & & 0.06 & 0.01 \\
\hline 48 & C13 Alkane ${ }^{4}$ & & 0.06 & 0.01 \\
\hline
\end{tabular}

$1 \mathrm{CAS}=$ Chemical Abstract Service. 2 When the analyte was detected in only 2 samples, the entry is the relative difference (i.e., their difference
divided by 2), values listed are estimates.

3 Detected in only 1 sample.

4 Detected in only 2 samples.

5 Average of 3 samples. 
Table 4-7

Tank BY-106 Tentatively Identified Organic Compounds in TST Samples in Order of Chromatographic Elution -Analyses Conducted by Oak Ridge National Laboratory

\begin{tabular}{|c|c|c|c|}
\hline $\begin{array}{c}\text { Cmpd } \\
\#\end{array}$ & Compound & $\begin{array}{c}\mathrm{CAS}^{1} \\
\text { Number }\end{array}$ & $\begin{array}{c}\text { Average }^{2} \\
\left(\mathrm{mg} / \mathrm{m}^{3}\right)\end{array}$ \\
\hline 1 & 2-Butene, (Z)- & $107-01-7$ & 0.527 \\
\hline 2 & 1-Propene, 2-methyl- & $115-11-7$ & 0.040 \\
\hline 3 & 1-Propene, 2-methyl- & $115-11-7$ & 0.125 \\
\hline 4 & 1-Propene, 2-methyl- & $115-11-7$ & 0.035 \\
\hline 5 & 1-Butene, 3-methyl- & $563-45-1$ & 0.053 \\
\hline 6 & Methyl ether & $115-10-6$ & 0.133 \\
\hline 7 & Butane, 2-methyl- & $78-78-4$ & 0.298 \\
\hline 8 & Methane, trichlorofluoro- & $75-69-4$ & 0.265 \\
\hline 9 & 1-Pentene & $109-67-1$ & 0.297 \\
\hline 10 & 1-Butyne and others & $107-00-6$ & 0.004 \\
\hline 11 & Propane, 2-methyl- & $75-28-5$ & 1.685 \\
\hline 12 & Furan & $110-00-9$ & 0.028 \\
\hline 13 & 1,3-Pentadiene, (E)- and C5-Alkene & $2004-70-8$ & 0.017 \\
\hline 14 & 2-Propanol & $67-63-0$ & 0.276 \\
\hline 15 & 2-Pentene, (Z)- & $627-20-3$ & 0.016 \\
\hline 16 & Cyclopentane & $287-92-3$ & 0.076 \\
\hline 17 & Cyciopropane, 1,1-dimethyl- & $1630-94-0$ & 0.026 \\
\hline 18 & 1-Pentyne and C4-alkene & $627-19-0$ & 0.018 \\
\hline 19 & 1,3-Pentadiene, (Z)- & $504-60-9$ & 0.027 \\
\hline 20 & Butane, 2,2-dimethyl- & $75-83-2$ & 0.005 \\
\hline 21 & 2-Propenenitrile and others & $107-13-1$ & 0.007 \\
\hline 22 & 1-Pentene, 4-methyl- & $691-37-2$ & 0.109 \\
\hline 23 & Cyclopentane & $287-92-3$ & 0.048 \\
\hline 24 & Pentane, 2-methyl- & $107-83-5$ & 0.699 \\
\hline 25 & C3-cyclopropane & & 0.045 \\
\hline 26 & 2,3-Dihydrofuran & $1191-99-7$ & 0.035 \\
\hline 27 & Cyçopropane, propyl- & $2415-72-7$ & 0.004 \\
\hline 28 & 1-Butene & $106-98-9$ & 0.005 \\
\hline 29 & Pentane, 3-methyl- & $96-14-0$ & 0.152 \\
\hline 30 & Propanenitrile & $107-12-0$ & 0.006 \\
\hline 31 & 1-Pentene, 2-methyl- & $763-29-1$ & 0.068 \\
\hline
\end{tabular}


WHC-SD-WM-ER-420 REV. 2

\begin{tabular}{|c|c|c|c|}
\hline $\begin{array}{c}\text { Cmpd } \\
\# \\
\end{array}$ & Compound & $\begin{array}{c}\text { CAS }^{1} \\
\text { Number }\end{array}$ & $\begin{array}{l}\text { Average }^{2} \\
\left(\mathrm{mg} / \mathrm{m}^{3}\right)\end{array}$ \\
\hline 32 & C6-alkene & & 0.169 \\
\hline 33 & 3-Buten-2-one & $78-94-4$ & 0.036 \\
\hline 34 & 2-Butanone & $78-93-3$ & 0.212 \\
\hline 35 & 2-Hexene, (Z)- & $7688-21-3$ & 0.023 \\
\hline 36 & 2-Pentene, 4-methyl-, (E)- & $674-76-0$ & 0.029 \\
\hline 37 & Alkanol & & 0.032 \\
\hline 38 & Cyclopropane, propyl- & $2415-72-7$ & 0.116 \\
\hline 39 & C6-alkene & & 0.025 \\
\hline 40 & Cyclopentane, methyl- & $96-37-7$ & 0.096 \\
\hline 41 & Alkenol & & 0.158 \\
\hline 42 & Furan, tetrahydro- & $109-99-9$ & 0.302 \\
\hline 43 & 1,3-Butadiene, 2,3-dimethyl- & $513-81-5$ & 0.048 \\
\hline 44 & 1,4-Hexadiene & $592-45-0$ & 0.033 \\
\hline 45 & 1H-Pyrrole and others & $109-97-7$ & 0.008 \\
\hline 46 & Mixture & & 0.007 \\
\hline 47 & 1-Hexene, 5-methyl- & $3524-73-0$ & 0.028 \\
\hline 48 & 2-Butenal & $4170-30-3$ & 0.015 \\
\hline 49 & Furan, 2,5-dihydro- & $1708-29-8$ & 0.029 \\
\hline 50 & 3-Butenenitrile & $109-75-1$ & 0.016 \\
\hline 51 & Hexane, 2-methyl- & $591-76-4$ & 0.044 \\
\hline 52 & 1-Hexene, 3,4-dimethyl- & $16745-94-1$ & 0.003 \\
\hline 53 & Pentane, 2,3-dimethyl- & $565-59-3$ & 0.001 \\
\hline 54 & Furan, 2-propyl- & $4229-91-8$ & 0.340 \\
\hline 55 & Cyclopentane, 1,3-dimethyl-, cis- & $2532-58-3$ & 0.002 \\
\hline 56 & C3-Cyclopentane & & 0.002 \\
\hline 57 & C6-alkenone & & 0.008 \\
\hline 58 & Cyclopentane, 1,2-dimethyl- & $2452-99-5$ & 0.010 \\
\hline 59 & C2-cyclopentane & & 0.066 \\
\hline 60 & 2-Pentanol & $6032-29-7$ & 0.009 \\
\hline 61 & 2-Heptene, $(E)$ - & $14686-13-6$ & 0.005 \\
\hline 62 & 2-Pentanone, 4-methyl- & $108-10-1$ & 0.010 \\
\hline 63 & 2-Heptene & $592-77-8$ & 0.001 \\
\hline 64 & Cyclohexane, methyl- & $108-87-2$ & 0.041 \\
\hline 65 & 1-Hexene, 2-methy!- & $6094-02-6$ & 0.001 \\
\hline
\end{tabular}




\begin{tabular}{|c|c|c|c|c|}
\hline $\begin{array}{c}\text { Cmpd } \\
\# \\
\end{array}$ & Compound & & $\begin{array}{c}\mathrm{CAS}^{1} \\
\text { Number } \\
\end{array}$ & $\begin{array}{c}\text { Average }^{2} \\
\left(\mathrm{mg} / \mathrm{m}^{3}\right) \\
\end{array}$ \\
\hline 66 & Hexane, 2,4-dimethyl- & & $589-43-5$ & 0.001 \\
\hline 67 & C7-alkene & & & 0.010 \\
\hline 68 & 2-Pentanol, 2-methyl- & & $590-36-3$ & 0.013 \\
\hline 69 & C6-Alkenone & & & 0.001 \\
\hline 70 & C8-Alkene & & & 0.002 \\
\hline 71 & 2-Pentanone, 4-methyl- & & $108-10-1$ & 0.010 \\
\hline 72 & Alkane & & - & 0.006 \\
\hline 73 & Mixture & & & 0.001 \\
\hline 74 & Mixture & & & 0.005 \\
\hline 75 & Cyclopropane, 1-heptyl-2methyl- & & $74663-91-5$ & 0.015 \\
\hline 76 & C8-Alkene & & & 0.001 \\
\hline 77 & Pentane, 3-ethyl-2-methyl- & & $609-26-7$ & 0.024 \\
\hline 78 & Heptane, 3-methyl- & & $589-81-1$ & 0.055 \\
\hline 79 & 1-Octen-3-one & & $4312-99-6$ & 0.017 \\
\hline 80 & Cyclohexane, 1,3-dimethyl-, cis- & & $638-04 \sim 0$ & 0.007 \\
\hline 81 & C2-cyclohexane & & & 0.001 \\
\hline 82 & 1,4-Hexadiene, 4-methyl- and others & & $1116-90-1$ & 0.001 \\
\hline 83 & 3-Hexanone & & 589-38-8 & 0.016 \\
\hline 84 & 1-Hexene, 4,5-dimethyl- & & $16106-59-5$ & 0.001 \\
\hline 85 & Hexanal & & $66-25-1$ & 0.010 \\
\hline 86 & Formamide, N-(2-methylpropyl)- & & $6281-96-5$ & 0.007 \\
\hline 87 & Alkanol & & & 0.003 \\
\hline 88 & 1-Pentanol, 5-methoxy- & & $4799-62-6$ & 0.003 \\
\hline 89 & Cyclopentane, 1,1,3-trimethyl- & & $4516-69-2$ & 0.005 \\
\hline 90 & Hexanal & & $66-25-1$ & 0.003 \\
\hline 91 & Ethene, tetrachloro- &.- & $127-18-4$ & 0.023 \\
\hline 92 & Acetic acid, butyl ester & & $123-86-4$ & 0.007 \\
\hline 93 & Hexamethylcyclotrisiloxane & & $541-05-9$ & 0.006 \\
\hline 94 & Pyridine, 4-methyl- & & $108-89-4$ & 0.007 \\
\hline 95 & Nitric acid, butyl ester & & $928-45-0$ & 0.000 \\
\hline 96 & Heptane, 2,6-dimethyl- & & $1072-05-5$ & 0.022 \\
\hline $97^{\prime}$ & 2-Pentanol, 2,3-dimethyl- & & $4911-70-0$ & 0.005 \\
\hline 98 & 4-Heptenal, (Z)- & & $6728-31-0$ & 0.002 \\
\hline 99 & Cyclohexane, ethyl- & & $1678-91-7$ & 0.011 \\
\hline
\end{tabular}




\begin{tabular}{|c|c|c|c|}
\hline $\begin{array}{c}\text { Cmpd } \\
\# \\
\end{array}$ & Compound & $\begin{array}{c}\text { CAS }^{1} \\
\text { Number }\end{array}$ & $\begin{array}{l}\text { Average }{ }^{2} \\
\left(\mathrm{mg} / \mathrm{m}^{3}\right)\end{array}$ \\
\hline 100 & Cyclohexane, 1,1,3-trimethyl- & $3073-66-3$ & 0.019 \\
\hline 101 & Hexane, 3-methoxy- & $54658-01-4$ & 0.009 \\
\hline 102 & 7-Octen-2-one & $3664-60-6$ & 0.007 \\
\hline 103 & Cyclobutanone, 2,3,3-trimethyl- & $28290-01-9$ & 0.011 \\
\hline 104 & Cyclohexane, 1,3,5-trimethyl- & $1839-63-0$ & 0.006 \\
\hline 105 & Heptane, 2,3-dimethyl- & $3074-71-3$ & 0.012 \\
\hline 106 & Octane, 2-methyl- & $3221-61-2$ & 0.020 \\
\hline 107 & Nitro-Compound & & 0.001 \\
\hline 108 & Octane, 3-methyl- & $2216-33-3$ & 0.024 \\
\hline 109 & Benzene, 1,3-dimethyl- & $108-38-3$ & 0.020 \\
\hline 110 & 4-Octen-3-one & $14129-48-7$ & 0.001 \\
\hline 111 & Cyclohexane, 1,2,3-trimethyl- & $1678-97-3$ & 0.001 \\
\hline 112 & Alkane & & 0.015 \\
\hline 113 & C3-cyclohexane and others & & 0.004 \\
\hline 114 & Acetamide, N,N-dimethyl- and others & $127-19-5$ & 0.001 \\
\hline 115 & 3-Heptanone & $106-35-4$ & 0.028 \\
\hline 116 & Styrene & $100-42-5$ & 0.005 \\
\hline 117 & Benzene, 1,4-dimethyi- & $106-42-3$ & 0.008 \\
\hline 118 & Heptanal & $111-71-7$ & 0.007 \\
\hline 119 & Cyclohexane, 1,1,3,5-tetramethyl-, trans- & $50876-31-8$ & 0.001 \\
\hline 120 & C3-Cyclohexane & & 0.001 \\
\hline 121 & Cyclohexane, 1-ethyl-4-methyl-, cis & $4926-78-7$ & 0.004 \\
\hline 122 & C7-alkañone & & 0.005 \\
\hline 123 & Mixture & & 0.002 \\
\hline 124 & Cyclopropene, 1-butyle-2-ethyl- & $50915-91-8$ & 0.016 \\
\hline 125 & Cyclohexanol, 3-methyl- and others & $591-23-1$ & 0.001 \\
\hline 126 & 2-Heptanol, 2-methyl- & $625-25-2$ & 0.003 \\
\hline 127 & Octane, 2,6-dimethyl- & $2051-30-1$ & 0.022 \\
\hline 128 & Cyclohexane, (1-methylethyl)- & $696-29-7$ & 0.002 \\
\hline 129 & Pyridine, 3,5-dimethyl- and others & $591-22-0$ & 0.004 \\
\hline 130 & Furan and others & $110-00-9$ & 0.001 \\
\hline 131 & Heptane, 3-ethyl-2-methyl- & $14676-29-0$ & 0.006 \\
\hline 132 & Mixture & & 0.003 \\
\hline 133 & 2-Heptanone, 6-methyl- & $928-68-7$ & 0.031 \\
\hline
\end{tabular}




\begin{tabular}{|c|c|c|c|}
\hline $\begin{array}{c}\text { Cmpd } \\
\#\end{array}$ & Compound & $\begin{array}{c}\text { CAS }^{1} \\
\text { Number }\end{array}$ & $\begin{array}{l}\text { Average }^{2} \\
\left(\mathrm{mg} / \mathrm{m}^{3}\right)\end{array}$ \\
\hline 134 & Benzene, propyl- & $103-65-1$ & 0.003 \\
\hline 135 & Nonane, 4-methyl- & $17301-94-9$ & 0.012 \\
\hline 136 & 1,1,2,3-tetramethylcyclohexane & $6783-92-2$ & 0.024 \\
\hline 137 & Alkenol & & 0.034 \\
\hline 138 & Alkene & & 0.010 \\
\hline 139 & C3-cyclohexene & & 0.003 \\
\hline 140 & 3-Penten-2-ol and others & & 0.002 \\
\hline 141 & 4-Octanone and others & & 0.002 \\
\hline 142 & Cyclopentane, 1-methyl-3-(2-methylpropyl)- & 29053-04-1 & 0.006 \\
\hline 143 & C3-Cyclohexene & & 0.001 \\
\hline 144 & Cyclohexane, 1-methyl-4-(-methylethyl)-, cis- & $6069-98-3$ & 0.006 \\
\hline 145 & Phenol & $108-95-2$ & 0.010 \\
\hline 146 & Cyclotetrasiloxane, octamethyl- & $556-67-2$ & 0.024 \\
\hline 147 & Butanoic acid, butyl ester & $109-21-7$ & 0.005 \\
\hline 148 & Decane & $124-18-5$ & 0.049 \\
\hline 149 & 4-Nonene, 5-methyl- & 15918-07-7 & 0.001 \\
\hline 150 & (Z)-2,3,4,5-tetramethyl-3-hexene & & 0.005 \\
\hline 151 & C5-cyclopentane & & 0.002 \\
\hline 152 & C4-Cyclohexane & & 0.001 \\
\hline 153 & Cyclopentane, 1-methyl-3-(2-methyipropyl)- & 29053-04-1 & 0.004 \\
\hline 154 & Heptane, 2,3,6-trimethyi- & $4032-93-3$ & 0.004 \\
\hline 155 & 3-Hexane, 2,2,5,5-tetramethyl-, (A)- and others & & 0.006 \\
\hline 156 & Nonane, 2,6-dimethyl- & $17302-28-2$ & 0.034 \\
\hline 157 & Cyclohexanol, 4-(1,1,3,3-tetramethylbutyl)-. & $4631-98-5$ & 0.004 \\
\hline 158 & 1-Hexanol, 2-ethyl & $104-76-7$ & 0.001 \\
\hline 159 & Undecane & $1120-21-4$ & 0.005 \\
\hline 160 & Cyclohexane, (1-methylpropyl)- & $7058-01-7$ & 0.014 \\
\hline 161 & Cyclopentane, 1-hexyl-3-methyl- & $61142-68-5$ & 0.001 \\
\hline 162 & 1,1,2,3-Tetramethylcyclohexane & $6783-92-2$ & 0.001 \\
\hline 163 & C5-cyclohexane & & 0.004 \\
\hline 164 & C4-cyclohexane & & 0.008 \\
\hline 165 & 1-Undecene & $821-95-4$ & 0.001 \\
\hline 166 & Mixture & & 0.001 \\
\hline 167 & Cyclohexanone, 2,6-diethyl- & $16519-68-9$ & 0.001 \\
\hline
\end{tabular}


WHC-SD-WM-ER-420 REV. 2

\begin{tabular}{|c|c|c|c|}
\hline $\begin{array}{c}\text { Cmpd } \\
\# \\
\end{array}$ & Compound & $\begin{array}{c}\text { CAS }^{1} \\
\text { Number }\end{array}$ & $\begin{array}{l}\text { Average }{ }^{2} \\
\left(\mathrm{mg} / \mathrm{m}^{3}\right)\end{array}$ \\
\hline 168 & 1,1-dimethyl-2-propylcyclohexane & & 0.017 \\
\hline 169 & Decane, 4-methyl- & $2847-72-5$ & 0.006 \\
\hline 170 & Decane, 2,6,7-trimethyl- & $62108-25-2$ & 0.016 \\
\hline 171 & Naphthalene, decahydro-, trans- & $493-02-7$ & 0.024 \\
\hline 172 & Mixture & & 0.001 \\
\hline 173 & Ethanone, 1-phenyl- & $98-86-2$ & 0.010 \\
\hline 174 & $\begin{array}{l}\text { 1-Naphthalenol, decahydro-4a-methyl-8- } \\
\text { methylene-2-(1-met) and others }\end{array}$ & $30951-17-8$ & 0.007 \\
\hline 175 & C5-cyclohexane & & 0.007 \\
\hline 176 & $\begin{array}{l}\text { Cyciohexane, 1,2-diethyl-1-methyl-Zinc, } \\
\text { bis[2-(1,1-dimethylethyl)-3,3-dimethylcyclopro }\end{array}$ & $61141-79-5$ & 0.005 \\
\hline 177 & C5-cyciohexane & & 0.016 \\
\hline 178 & 2-Nonanone & $821-55-6$ & 0.004 \\
\hline 179 & C6-cyclohexane & & 0.005 \\
\hline 180 & Undecane & $1120-21-4$ & 0.071 \\
\hline 181 & 5-Undecene & $4941-53-1$ & 0.005 \\
\hline 182 & C11-alkene & & 0.006 \\
\hline 183 & Cyclopropane, octyl- & $1472-09-9$ & 0.004 \\
\hline 184 & Undecane, 5-methyl- & $1632-70-8$ & 0.012 \\
\hline 185 & Cyclohexene, 1-pentyl- & $15232-85-6$ & 0.006 \\
\hline 186 & Naphthalene, decahydro-2-methyl- & $2958-76-1$ & 0.030 \\
\hline 187 & C6-Alkenyl-cyclopentane & & 0.001 \\
\hline 188 & 5-Dodecene, (Z)- & $7206-28-2$ & 0.006 \\
\hline 189 & Benzoic acid, 2-[(trimethylsilyl)oxyl-, trimethylsilyl ester & $3789-85-3$ & 0.004 \\
\hline 190 & Cyclohexane, pentyl- & $4292-92-6$ & 0.014 \\
\hline 191 & Naphthalene, decahydro-2-methyl- & $2958-76-1$ & 0.025 \\
\hline 192 & Decane, 2,4-dimethyl- & $2801-84-5$ & 0.003 \\
\hline 193 & 6-Methylundecane & $17302-33-9$ & 0.023 \\
\hline 194 & Undecane, 4-methyl- & $2980-69-0$ & 0.012 \\
\hline 195 & Undecane, 2-methyl- & $7045-71-8$ & 0.019 \\
\hline 196 & C6-cyclohexane & & 0.006 \\
\hline 197 & Undecane, 3-,methyl- & $1002-43-3$ & 0.009 \\
\hline 198 & 2-Cyclohexen-1-one, 4-ethyl-3,4-dimethyl- & $17622-46-7$ & 0.003 \\
\hline 199 & 2-Propyl-1,1,3-trimethylcyclohexane & & 0.005 \\
\hline
\end{tabular}




\begin{tabular}{|c|c|c|c|}
\hline $\begin{array}{c}\text { Cmpd } \\
\# \\
\end{array}$ & Compound & $\begin{array}{c}\mathrm{CAS}^{1} \\
\text { Number }\end{array}$ & $\begin{array}{c}\text { Average }^{2} \\
\left(\mathrm{mg} / \mathrm{m}^{3}\right)\end{array}$ \\
\hline 200 & Naphthalene, decahydro-2,3-dimethyl- & $1008-80 \ldots$ & 0.007 \\
\hline 201 & Decane, 2,3,6-trimethyl- & $62238-12-4$ & 0.007 \\
\hline 202 & Mixture - & . & 0.001 \\
\hline 203 & Cyclohexane, 1,-methyi-3-pentyl- & $54411-02-8$ & 0.002 \\
\hline 204 & Cyclopentane, 2-isopropyl-1,3-dimethyl- & $32281-85-9$ & 0.006 \\
\hline 205 & Naphthalene, decahydro-1,6-dimethyl- & $1750-51-2$ & 0.001 \\
\hline 206 & Cyclohexane, 1-ethyl-2-methyl-, cis- & $4923-77-7$ & 0.016 \\
\hline 207 & Undecane, 2,6-dimethyl- & $17301-23-4$ & 0.027 \\
\hline 208 & C2-Decahydronaphthalene & & 0.005 \\
\hline 209 & Undecane, 4,8-dimethyl- & $17301-33-6$ & 0.006 \\
\hline 210 & C2-Decahydronaphthalene & & 0.003 \\
\hline 211 & Naphthalene, decahydro-1,5-dimethyl- & $66552-62-3$ & 0.010 \\
\hline 212 & 4-Nonene, 5-butyl- & $7367-38-6$ & 0.019 \\
\hline 213 & $(E, E)(3 S, 8 S), 3,8$-dimethyldeca-4,6-diene & & 0.015 \\
\hline 214 & C7-Cyclohexane & & 0.002 \\
\hline 215 & Naphthalene, decahydro-1,6-dimethyl- & $1750-51-2$ & 0.001 \\
\hline 216 & C7-Cyclohexane & & 0.009 \\
\hline 217 & Undecane, 2,10-dimethyl- & $17301-27-8$ & 0.019 \\
\hline 218 & Tridecane, 7-methyl- & $26730-14-3$ & 0.049 \\
\hline 219 & Cyclohexane, 1,2-diethyl-3-methyl- & $61141-80-8$ & 0.007 \\
\hline 220 & 2(3H)-Benzofuranone, 3a,4,5,6-tetrahydro-3a,6,6-trimethyl- & $16778-26-0$ & 0.010 \\
\hline 221 & 6-Tridecene, 7-methyl- & $24949-42-6$ & 0.022 \\
\hline 222 & Phenol, 4-(1,1-dimethylethyl)- and others & & 0.004 \\
\hline 223 & Cyclohexane, (2-ethyl-1-methyl-1-butenyl)- & $74810-42-7$ & 0.002 \\
\hline 224 & Undecane, 6-ethyl- & $17312-60-6$ & 0.001 \\
\hline 225 & Dodecane, 2,5-dimethyl- & $56292-65-0$ & 0.010 \\
\hline 226 & C8-Cyclohexane & & 0.004 \\
\hline 227 & C8-Cyclohexane & . & 0.006 \\
\hline 228 & 7-Tetradecene & $10374-74-0$ & 0.004 \\
\hline 229 & 2-Octylfuran & $4179-38-8$ & 0.006 \\
\hline 230 & Cyclohexane, octyl- & $1795-15-9$ & 0.012 \\
\hline 231 & Tridecane, 4-methyl- & $26730-12-1$ & 0.005 \\
\hline 232 & Tridecane, 2-methyl- & $1560-969$ & 0.006 \\
\hline 233 & C1-acridine and others & & 0.021 \\
\hline
\end{tabular}




\begin{tabular}{|c|c|c|c|}
\hline $\begin{array}{c}\text { Cmpd } \\
\#\end{array}$ & Compound & $\begin{array}{c}\mathrm{CAS}^{1} \\
\text { Number }\end{array}$ & $\begin{array}{l}\text { Average }^{2} \\
\left(\mathrm{mg} / \mathrm{m}^{3}\right)\end{array}$ \\
\hline 234 & Dodecane, 2,6,10-trimethyl- & $3891-98-3$ & 0.061 \\
\hline 235 & Tetradecane & $629-59-4$ & 0.045 \\
\hline 236 & Tridecane, 4,8-dimethyl- & $55030-62-1$ & 0.012 \\
\hline 237 & 1,1,2,3-tetramethylcyclohexane & $6783-92-2$ & 0.019 \\
\hline 238 & Cyclopentane, (1-methylbutyl)- & $4737-43-3$ & 0.007 \\
\hline 239 & Cyclohexane, 1,1,3,5-tetramethyl-, cis- & $50876-32-9$ & 0.001 \\
\hline 240 & 1-Pentadecene & $13360-61-7$ & 0.001 \\
\hline 241 & Alkane & & 0.001 \\
\hline 242 & C16-Alkane & . & 0.006 \\
\hline 243 & Dodecane, 2-methyl-8-propyl- & $55045-07-3$ & 0.057 \\
\hline 245 & Pentadecane, 2-methyl- & $1560-93-6$ & 0.003 \\
\hline 246 & Alkane & & 0.004 \\
\hline 247 & 3-tert-butyl-4-methoxphenol & $88-32-4$ & 0.000 \\
\hline 248 & Phenol, (1,1-dimethylethyl)-4-methoxy- & $25013-16-5$ & 0.001 \\
\hline 249 & 7-Hexadecene, (Z)- & $35507-09-6$ & 0.010 \\
\hline 250 & Pentadecane & $629-62-9$ & 0.043 \\
\hline 251 & 3,4-Undecadiene-2,10-dione, 6,6-dimethyl- & $52588-78-0$ & 0.000 \\
\hline 252 & c9-Cyclohexane & & 0.000 \\
\hline 253 & Tridecane, 2-methyl- & $1560-96-9$ & 0.005 \\
\hline 254 & Alkane & & 0.004 \\
\hline 255 & Alkane & $\cdots$ & 0.005 \\
\hline 256 & Alkane & & 0.000 \\
\hline 257 & Hexadecane, 3-methyl- & $6418-43-5$ & 0.001 \\
\hline 258 & 5-Undecanone, 2-methyl- & $50639-02-6$ & 0.001 \\
\hline 259 & Hexadecane & $544-76-3$ & 0.015 \\
\hline 260 & 1,2-Benzenedicarboxylic acid, diethyl ester & $84-66-2$ & 0.038 \\
\hline 261 & Pentadecane, 2,6,10-trimethyl- & $3892-00-0$ & 0.006 \\
\hline 262 & 1-Hexadecanol & $36653-82-4$ & 0.003 \\
\hline 263 & Heptadecane & $629-78-7$ & 0.003 \\
\hline 264 & Pentadecane, 2,6,10,14-tetramethyl- & $1921-70-6$ & 0.004 \\
\hline 265 & Alkane & & 0.004 \\
\hline 266 & 1,1'-Biphenyl, 2,2'-diethyl- & $13049-35-9$ & 0.000 \\
\hline 267 & Tetradecanoic acid & $544-63-8$ & 0.008 \\
\hline 268 & Benzenesulfonamide, N-butyl- & $3622-84-2$ & 0.034 \\
\hline
\end{tabular}


WHC-SD-WM-ER-420 REV. 2

\begin{tabular}{clrc}
\hline \hline $\begin{array}{c}\text { Cmpd } \\
\#\end{array}$ & Compound & $\begin{array}{c}\text { CAS }^{1} \\
\text { Number }\end{array}$ & $\begin{array}{c}\text { Average }^{2} \\
\left(\mathrm{mg} / \mathrm{m}^{3}\right)\end{array}$ \\
\hline \hline 269 & Pentadecanoic acid & $1002-84-2$ & 0.002 \\
270 & 1-Hexadecanol & $36653-82-4$ & 0.003 \\
271 & Alkene and others & & 0.004 \\
272 & Hexadecanoic acid & $57-10-3$ & 0.013 \\
273 & Pthalate & & 0.001 \\
274 & Hexadecanoic acid & $57-10-3$ & 0.003 \\
\hline \hline
\end{tabular}

$1 \mathrm{CAS}=$ Chemical Abstract Service.

2 Average includes samples with zero concentration, values listed are estimates. 


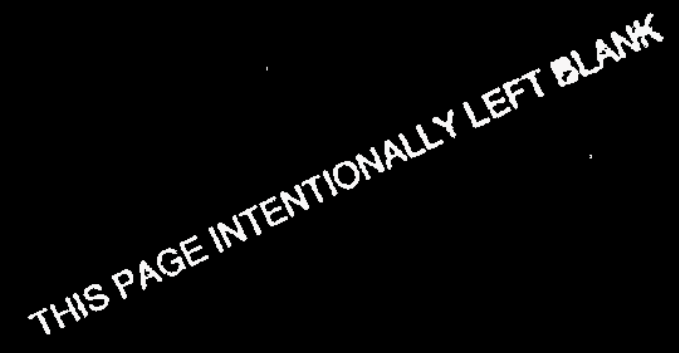

